\title{
Exploratory Factor Analysis (EFA) Pada Penyerapan Anggaran Pendapatan dan Belanja Negara (APBN) Tahun 2017 di Provinsi Sumatera Barat
}

\author{
Aulia Rahim dan Harsya Saputra \\ Kalwil DJPb Prov. Sumbar, Direktorat Jenderal Perbendaharaan \\ Alamat Korespondensi: aoely3@gmail.com
}

INFORMASI ARTIKEL

Diterima Pertama

8 Juni 2018

Dinyatakan Diterima

06 Desember 2018

KATA KUNCI:

back-loaded, eigenvalue, exploratory factor analysis

KLASIFIKASI JEL:

\begin{abstract}
ABSTRAK
Slow back-loaded pattern highlights challenges and raises a specific concern over the quality of state budget (APBN) implementation in West Sumatera Province. This study aims to investigate factors constraining state budget ( $A P B N$ ) absorption in 2017 which directly causes the existence of such a pattern. A set of questionnaires were used to collect primary data. Exploratory Factor Analysis (EFA) was utilized to identify latent variables underlying the scale and SPSS.22 was employed to test questionnaires from 200 working units that involved in this research. The findings explain that six main factors influencing state budget absorption in West Sumatera were a. Goods and Services Procurement, $b$. Internal Policy Changes, c. Budget Planning, d. Financial Officers, e.Changes on Government Policy and f. Document Verification Process on Budget Execution. This study recommends that working units should prepare for early procurement to expedite the budget absorption.
\end{abstract}

Pola slow back-loaded merupakan tantangan terhadap kualitas pelaksanaan APBN di Sumatera Barat. Studi ini bertujuan untuk menginvestigasi faktor-faktor yang mempengaruhi penyerapan APBN di Sumatera Barat pada tahun 2017 yang secara langsung mempengaruhi pola penyerapan yang terjadi. Satu set kuesioner digunakan untuk mendapatkan data primer yang dibutuhkan. Teknik analisis faktor eksploratori digunakan untuk mengidentifikasi variabel laten yang ada dan SPSS 22 digunakan untuk melakukan tes statistik terhadap kuesioner yang diperoleh dari 200 satker yang terlibat di penelitian ini. Hasil penelitian menjelaskan bahwa enam faktor yang berpengaruh terhadap penyerapan APBN di Provinsi Sumatera Barat yaitu a. Faktor Proses Lelang Pengadaan Barang dan Jasa, b. Faktor Perubahan Kebijakan Internal Satuan Kerja dan K/L, c. Faktor Administrasi Perencanaan Anggaran, d. Faktor Pejabat Perbendaharaan, e. Faktor Perubahan Kebijakan Pemerintah dan f. Faktor Proses Verifikasi Dokumen Untuk Pelaksanaan Anggaran. Studi ini salah satunya merekomendasikan percepatan pelaksanaan pengadaan barang dan jasa untuk mempercepat penyerapan anggaran. 


\section{PENDAHULUAN}

\subsection{Latar Belakang}

Kebijakan fiskal pemerintah yang dijabarkan dalam Anggaran Pendapatan dan Belanja Negara (APBN) merupakan instrumen penting dalam mengelola perekonomian dan dalam upaya mewujudkan cita-cita kemerdekaan negara Indonesia. Pada tahun anggaran (TA) 2017, pemerintah berupaya untuk mewujudkan pengelolaan APBN yang lebih kredibel dengan tetap memfokuskan sumber daya fiskal untuk mewujudkan agenda Nawa Cita di tengah-tengah masih dihadapinya potensi tantangan internal berupa keterbatasan ruang fiskal (fiscal space gap), mandatory dan non discretionary spending yang masih cukup besar, dan permasalahan dalam pencapaian kuantitas dan kualitas output belanja yang perlu ditingkatkan.

Sebagai instrumen utama kebijakan fiskal pemerintah, APBN diharapkan dapat menciptakan kondisi makro ekonomi yang dapat mendukung tercapainya target pertumbuhan ekonomi yang ditetapkan. APBN 2017 sebagaimana telah ditetapkan dalam Undang-Undang (UU) Nomor 18 Tahun 2016 memiliki alokasi belanja negara secara nasional sebesar Rp 2.080,45 triliun. Dari jumlah tersebut, total pagu APBN 2017 yang dialokasikan untuk 751 satuan kerja di Provinsi Sumatera Barat adalah sebesar Rp 13,30 triliun, atau naik sebesar Rp 3 trilun dibandingkan dengan alokasi belanja pada APBN-P Tahun 2016. Peningkatan alokasi belanja ini salah satunya disebabkan adanya pengalihan pencairan dana Transfer ke Daerah dan Dana Desa (TKDD) khususnya DAK Fisik dan Dana Desa sebesar Rp 2,70 triliun yang semula melalui KPPN Jakarta II sekarang dilakukan melalui KPPNKPPN di daerah. Perkembangan pagu dan realisasi APBN di wilayah Provinsi Sumatera Barat selama 6 tahun terakhir (2012-2017) tersaji pada grafik 1

Grafik 1. Pagu dan Realisasi APBN Provinsi Sumatera Barat Tahun 2012-2017

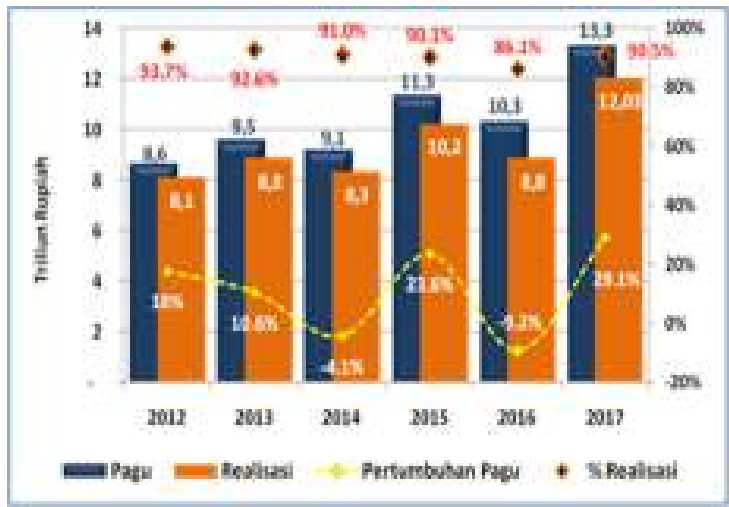

Sumber : Kanwil DJPb Prov Sumbar, diolah (2018)
Mengingat kucuran dana APBN yang cukup besar di Provinsi Sumatera Barat, maka APBN sesuai fungsinya yaitu fungsi alokasi, distribusi dan stabilisasi, diharapkan dapat menjadi penggerak utama dalam menciptakan lapangan pekerjaan sehingga dapat menekan angka pengangguran, mengendalikan tingkat inflasi dan mendorong distribusi pendapatan yang merata di wilayah provinsi Sumatera Barat.

Dalam pelaksanaannya, secara aggregat tingkat penyerapan APBN TA 2017 telah mencapai $90,5 \%$ atau sedikit di atas target penyerapan nasional yang dipatok di level $90 \%$. Hanya belanja modal yang terserap dibawah target penyerapan $90 \%$, tepatnya di angka 87\%. Realisasi penyerapan pagu DIPA 2017 perjenis belanja dapat dilihat pada grafik di bawah.

Grafik 2. Pagu dan Realisasi DIPA Per Jenis Belanja TA2017

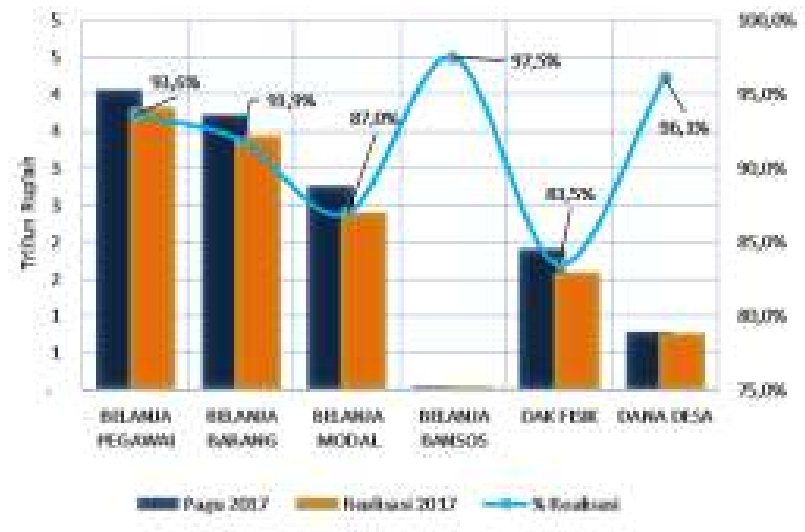

Sumber : Kanwil DJPb Prov Sumbar, diolah (2018)

Meskipun demikian, belanja APBN tahun 2017 di Sumatera Barat masih menunjukkan karakteristik yang tidak jauh berbeda dibandingkan dengan tahun-tahun sebelumnya, yaitu rendah di awal tahun dan meningkat tajam pada akhir tahun. Hal itu terlihat dari Tren realisasi ini seperti tergambar pada Grafik 3.

Grafik 3. Tren Belanja APBN Sumbar Tahun 2012-2017

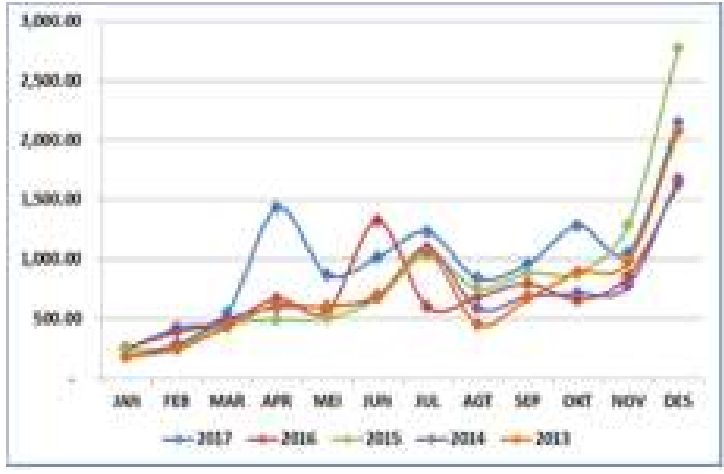

Sumber : Kanwil DJPb Provinsi Sumbar, 2018 (diolah) 
Selain itu, apabila dilihat dari tren penyerapan pagu non akumulatif per jenis belanja pada DIPA Tahun Anggaran 2017 (grafik 4), terlihat jelas pola penyerapan yang rendah di awal tahun dan meningkat tajam pada akhir akhir triwulan terjadi pada komponen belanja modal, belanja barang dan belanja bantuan sosial. Hanya belanja pegawai yang menunjukkan pola penyerapan yang cenderung stabil, meskipun terlihat lonjakan penyerapan di bulan Juni dan Juli terkait dengan adanya pembayaran gaji dan tunjangan ke-13 dan 14. Hal tersebut lebih disebabkan karena pada komponen belanja pegawai, sebagian besar pagunya digunakan untuk pembayaran gaji dan tunjangan pegawai yang cenderung sama dan tidak berfluktuatif di setiap bulannya.

Grafik 4. Tren Penyerapan Per Jenis Belanja Non Akumulatif TA 2017

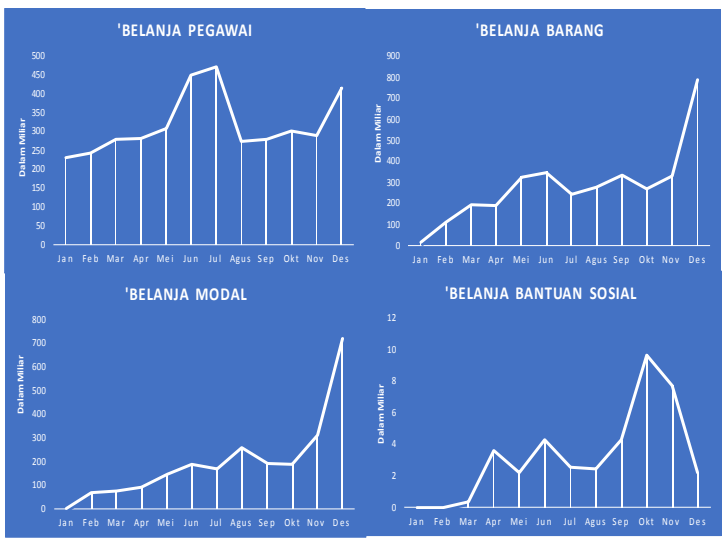

Sumber : Kanwil DJPb Provinsi Sumbar, 2018 (diolah)

Bank dunia menyebut fenomena penyerapan seperti yang terlihat pada grafik 4 sebagai fenomena "slow back-loaded expenditure" yaitu penyerapan anggaran yang rendah pada awal sampai dengan pertengahan tahun, akan tetapi mengalami perlonjakan yang signifikan di akhir tahun anggaran. Pola yang demikian diyakini kurang dapat memberikan stimulus terhadap perekonomian di Provinsi Sumatera Barat di tahun 2017.

Seperti yang diketahui bahwa faktor konsumsi masih merupakan variabel yang paling dominan dalam mendorong pertumbuhan ekonomi di Indonesia termasuk di Sumatera Barat. Menurut release data BPS Provinsi Sumatera Barat nomor 10/02/13/Th.XXI tanggal 5 Februari 2018, struktur PDRB Sumatera Barat menurut pengeluaran atas dasar harga berlaku tahun 2017 masih didominasi oleh komponen Pengeluaran Konsumsi Rumah Tangga (PKRT), Pembentukan Modal Tetap Bruto (PMTB) dan Pengeluaran Konsumsi Pemerintah. Pola Slow back-loaded expenditure dapat menyebabkan efek stimulus yang diharapkan dari government spending menjadi tidak optimal, sehingga akan berpengaruh secara langsung terhadap capaian pertumbuhan ekonomi yang juga tidak optimal.

\subsection{Rumusan Masalah}

Bertolak dari uraian di atas, penelitian ini ingin merumuskan faktor-faktor apa saja yang secara signifikan mempengaruhi pola penyerapan slow back-loaded expenditure pada satuan kerja di lingkup Provinsi Sumatera Barat, utamanya pada pelaksanaan APBN Tahun Anggaran 2017.

\subsection{Tujuan dan Manfaat Penelitian}

Dengan mengacu pada perumusan masalah di atas, penelitian ini ditujukan untuk menganalisis faktor-faktor utama penyebab pola slow backloaded expenditure pada level satuan kerja di Provinsi Sumatera Barat. Selanjutnya hasil penelitian ini, diharapkan dapat memberikan rekomendasi pada level kebijakan dan juga strategi implementasi yang tepat yang bersifat teknis dan aplikatif sehingga dapat menjadi alternatif solusi dalam menyelesaikan permasalahan yang timbul. Selain itu juga diharapkan agar penelitian ini dapat menjadi acuan atau studi literatur terkait permasalahan penyerapan anggaran dan pola back-loaded expenditure khususnya yang terjadi di Indonesia.

\section{KERANGKA TEORI}

\subsection{Pengertian Anggaran dan Anggaran Negara}

Secara etimologis kata anggaran berasal dari istilah 'anggar' yang berarti kira-kira atau perhitungan. Di negara Inggris, istilah anggaran diartikan sebagai 'budget' yang sebenarnya berasal dari bahasa Perancis yaitu 'Bougtte atau Bouge' yang artinya tas kulit yang ditaruh di pinggang, yang dahulu sering digunakan oleh pejabat keuangan negara Perancis untuk menyimpan dokumen-dokumen penting terkait anggaran negara. Sedangkan di Belanda, kata anggaran lebih dikenal dengan istilah 'Begrooting' yang artinya mengirakan.

Menurut Freeman (1972), anggaran adalah rencana keuangan dalam periode waktu tertentu yang mengestimasikan rencana pengeluaran yang akan dilaksanakan serta mencantumkan sumber pendapatan yang akan digunakan untuk membiayai rencana pengeluaran tersebut. Senanda dengan apa yang diutarakan oleh Freeman, Suparmoko (2000) memandang anggaran sebagai pernyataan yang dibuat secara rinci mengenai penerimaan dan pengeluaran dalam jangka waktu tertentu yang biasanya dilakukan dalam satu tahun.

Di dalam Undang-Undang Dasar Negara Republik Indonesia Tahun 1945, istilah Anggaran Negara termaktub dalam Pasal 23 ayat 1 yang 
menyatakan "Anggaran Pendapatan dan Belanja Negara sebagai wujud dari pengelolaan keuangan negara ditetapkan setiap tahun dengan undangundang dan dilaksanakan secara terbuka dan bertanggung jawab untuk sebesar-besarnya kemakmuran rakyat". Selanjutnya menurut Undang-Undang Nomor 17 tahun 2003 tentang Keuangan Negara, Anggaran Pendapatan dan Belanja Negara (APBN) diartikan sebagai rencana keuangan tahunan pemerintahan negara yang disetujui oleh Dewan Perwakilan Rakyat.

\subsection{Penyerapan Anggaran}

Dalam kajian Bersama yang dibuat oleh Bank Dunia, Badan Kebijakan Fiskal Kementerian Keuangan RI dan Universitas Indonesia dalam "Identifying the Constraints to Budget Execution in the Infrastructure Sector" (2012), ditemukan bahwa penyerapan yang terjadi di beberapa Kementerian, utamanya yang bergerak di sektor infrastruktur, mengalami pola penyerapan yang diistilahkan sebagai slow back-loaded expenditure. Penyerapan di awal sampai dengan pertengah tahun cenderung lambat dan akan meningkat secara drastis di penghujung tahun anggaran. Pola yang demikan dianggap oleh Siswanto dan Rahayu (2010) akan berakibat negatif pada rencana kebijakan APBN yang sudah disusun sebelumnya. Siswanto dan Rahayu (2010) menambahkan bahwa pola yang terjadi juga akan berdampak pada pertumbuhan ekonomi yang kurang optimal, dikarenakan penyerapan tenaga kerja yang merupakan stimulus untuk mengatasi kemiskinan tidak dapat dioptimalkan sejak awal tahun anggaran.

Penyerapan anggaran itu sendiri diartikan Halim (2013) sebagai realisasi dari pelaksanaan anggaran yang merupakan capaian dari estimasi anggaran selama periode waktu tertentu. Penyerapan anggaran dianggap optimal apabila pelaksanaan pekerjaan telah dieksekusi sesuai dengan dokumen perencanaan yang dibuat (Nugroho \& Ananda, 2012). Penyerapan anggaran yang rendah atau tidak optimal merupakan salah satu indikator kinerja yang kurang baik, meskipun memang bukan satu-satunya indikator yang digunakan dalam menilai kinerja Pemerintah. Yang perlu diingat adalah ditengah-tengah sumber penerimaan negara yang terbatas, pemerintah diwajibkan untuk mengutamakan kegiatankegiatan prioritas dalam penyusunan alokasi anggaran. Hal ini dilakukan agar pelaksanaan anggaran dapat dilaksanakan dengan lebih efektif dan efisien. Tingkat penyerapan yang rendah dalam hal ini mengindikasikan adanya manfaat belanja yang tidak dapat dioptimalkan karena dana yang disediakan tidak sepenuhnya terserap.

Halim (2013) berpendapat bahwa dalam konteks penganggaran berbasis kinerja, yang lebih diutamakan adalah bagaimana anggaran dapat digunakan untuk mencapai target output atau kinerja yang diharapkan. Akan tetapi juga perlu diingat bahwa anggaran merupakan kebijakan fiskal utama pemerintah yang digunakan untuk mendorong pertumbuhan ekonomi. Penyerapan yang optimal, khususnya di belanja yang mempunyai efek pengganda seperti belanja modal dan belanja sosial, dalam jangka pendek dapat memberikan efek stimulus yang dapat mendorong perekonomian melalui penciptaan lapangan pekerjaan dan peningkatan daya beli masyarakat. Penyerapan anggaran yang terkonsentrasi pada akhir tahun anggaran akan berdampak pada tidak optimalnya daya dorong atau stimulus yang diharapkan terjadi. Oleh karena itu, pola slow-back loaded yang timbul pada saat ini merupakan tantangan utama terhadap kapasitas dan kualitas pelaksanaan anggaran yang tentunya harus menjadi fokus perbaikan bagi pemerintah.

\subsection{Penelitian Terdahulu}

Penelitian ini merupakan pengembangan lebih lanjut dari penelitian terdahulu yang dilakukan oleh beberapa penulis dengan melakukan beberapa modifikasi pada objek dan responden penelitian. Studi empiris terdahulu antara lain dilakukan oleh :

a. Adrianus Dwi Siswanto dan Sri Lestari Rahayu (2010) yang memfokuskan studinya pada penyerapan anggaran di tujuh kementerian/ lembaga. Penelitian tersebut menyimpulkan bahwa permasalahan terkait internal satuan kerja, pengadaan barang dan jasa, permasalahan terkait revisi DIPA dan masalah lainnya merupakan penyebab utama rendahnya penyerapan anggaran yang terjadi.

b. Kuswoyo (2012) meneliti faktor utama penyebab terjadinya lonjakan penyerapan anggaran di akhir tahun anggaran pada satker KPPN Kediri. Hasil penelitian menunjukkan adanya empat faktor utama penyebab penumpukan anggaran dimaksud yaitu, faktor perencanaan anggaran, pelaksanaan anggaran, pengadaan barang dan faktor internal satuan kerja.

c. Baridwan (2012) meneliti hal yang sama dengan yang dilakukan oleh Kuswoyo dengan melakukan modifikasi atau perubahan objek penelitian dan menggunakan metode analisis yang berbeda. Hasil penelitian yang didapat menunjukkan kesimpulan yang sama dengan apa yang diteliti oleh Kuswoyo.

d. Herriyanto (2012) menggunakan teknik analisis faktor untuk mengungkapkan faktor-faktor utama penyebab terjadinya keterlambatan atau rendahnya penyerapan anggaran pada satkersatker KPPN Jakarta I dan KPPN Jakarta IV. Hasil penelitian yang dilakukan menyimpulkan 
bahwa lima faktor penyebab keterlambatan penyerapan anggaran adalah faktor perencanaan, administrasi, sumber daya manusia, dokumen pengadaan dan faktor uang persediaan.

e. Setyawan (2017) dalam tesisnya meneliti keterlambatan penyerapan anggaran pada satker KPPN Bojonegoro dengan menggunakan teknik analisis kualitatif. Dalam kesimpulannya, beberapa faktor yang menyebabkan keterlambatan dimaksud adalah faktor perencanaan anggaran, faktor pengadaan barang dan jasa dan faktor sumber daya manusia.

\section{METODOLOGI PENELITIAN}

\subsection{Pendekatan Penelitian}

Untuk mengungkapkan faktor-faktor utama penyebab terjadinya pola slow back-loaded pada satuan kerja Kementerian/lembaga di Provinsi Sumatera Barat, penulis menggunakan pendekatan kuantitatif dengan menggunakan teknik analisis Exploratory Factor Analysis (EFA). Menurut Widarjono (2015) dalam bukunya "Analisis Multivariat Terapan Dengan Program SPSS, AMOS, dan SMARTPLS" analisis faktor adalah teknik mencari faktor yang mampu menjelaskan hubungan berbagai indikator independen yang diobservasi. Melalui analisis faktor dapat diketahui faktor apa saja yang paling berpengaruh terhadap permasalahan pelaksanaan anggaran, utamanya penyerapan anggaran belanja satuan kerja Kementerian/Lembaga di wilayah Provinsi Sumatera Barat.

\subsection{Pengumpulan Data}

Data primer yang digunakan dalam studi ini merupakan data yang didapatkan dari kuisioner terstruktur yang terdiri dari pertanyaan tertutup dan terbuka. Pertanyaan tertutup diukur dengan menggunakan skala ordinal berupa Likert. Pengukuran didasarkan pada skala 1 sampai 5 dengan kriteria sebagai berikut:
a. Sangat Setuju;
b. Setuju;
c. Kurang Setuju;
d. Tidak Setuju;
e. Sangat Tidak Setuju.

Sedangkan pertanyaan terbuka diberikan untuk mengakomodasi permasalahan lainnya yang tidak terangkum dalam pertanyaan-pertanyaan tertutup. Sejumlah 35 pertanyaan tertutup dan 3 pertanyaan terbuka dimasukkan ke dalam variabel pertanyaan di dalam kuisioner yang dipakai. Variabel-variabel pertanyaan yang digunakan disimpulkan dari studi literatur, focus group discussion (FGD) dan hasil dari kegiatan rapat koordinasi pelaksanaan anggaran (rakor PA) dan evaluasi pelaksanaan anggaran (EPA) triwulan I s.d IV selama periode tahun 2017.

Populasi yang disasar dalam kuisioner adalah Pejabat Perbendaharaan Negara Non Bendahara (KPA, PPK dan PPSPM), Bendahara Pengeluaran dan Staff Pengelola Keuangan/Operator Satker yang ada di wilayah bayar KPPN-KPPN di lingkup Kanwil DJPb Provinsi Sumatera Barat yaitu KPPN Padang, KPPN Bukittinggi, KPPN Solok, KPPN Lubuk Sikaping, KPPN Painan dan KPPN Sijunjung. Sebanyak 315 kuesioner disebar ke 315 satuan kerja di wilayah Provinsi Sumatera Barat. Hal ini didasarkan pada pendapat Hair et all (1998) yang menyatakan bahwa jumlah minimum sampel yang dibutuhkan untuk melakukan analisis faktor adalah minimal 5 kali dari banyaknya variabel atau atribut di dalam kuisioner yang digunakan.

\subsection{Analisis Faktor}

Analisis yang digunakan adalah metode atau teknik Exploratory Factor Analysis, dimana sejumlah indikator dicari untuk membentuk faktor umum tanpa ada landasan teori sebelumnya atau merupakan sebuah metode untuk membangun teori. Analisis faktor ini menggunakan bantuan SPSS.22 for windows dalam pengerjaannya. Langkah pertama yang digunakan dalam analisis faktor menurut Supranto (2004) adalah merumuskan masalah dan melakukan identifikasi variabel-variabel yang akan digunakan dalam analisis faktor. Supranto (2004) kemudian menjelaskan bahwa langkah berikutnya adalah membentuk matriks korelasi dari variabel yang digunakan. Selanjutnya ditentukan banyaknya faktor yang akan dipilih (extracted) dengan menggunakan metode rotasi. Langkah terakhir menurut Supranto (2004) adalah menginterpretasikan faktor hasil rotasi.

Sebelum melakukan analisis faktor, perlu juga dilakukan uji validitas, uji reliabilitas dan uji korelasi terhadap data primer yang digunakan. Dari analisis faktor akan didapatkan faktor-faktor baru yang terbentuk dari variabel-variabel apa saja yang berpengaruh terhadap permasalahan penyerapan anggaran. Secara umum langkahlangkah yang digunakan dalam analisis faktor adalah sebagaimana tersaji pada gambar 1 .

Gambar 1. Langkah-langkah Analisis Faktor 


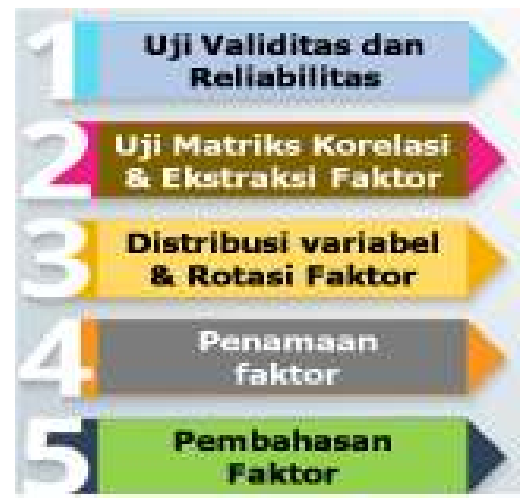

\subsubsection{Uji Validitas Instrumen}

Pengajuan validitas digunakan untuk mengukur valid tidaknya suatu kuesioner dimana kuesioner yang valid memiliki pertanyaan yang mampu mengungkapkan sesuatu yang akan diukur oleh kuesioner tersebut. Pengujian ini dilakukan dengan membandingkan nilai $r$ hitung dan $r$ tabel. Nilai $\mathrm{r}$ hitung dihasilkan dari nilai Corrected Item Total Correlation yang didapatkan dengan $\mathrm{r}$ tabel dengan $\mathrm{DF}=\mathrm{n}-2$ dan nilai signifikansinya 95\% $(\alpha=5 \%)$. Suatu instrumen dikatakan valid jika $r$ hitung>dari nilai $r$ tabel.

\subsubsection{Uji Reliabilitas}

Setelah melakukan uji validitas, langkah berikutnya adalah melakukan uji reliabilitas. Pengujian reliabilitas dimaksudkan untuk mengetahui apakah jawaban responden terhadap pertanyaan adalah konsisten atau stabil dari waktu ke waktu. Uji reliabilitas juga menunjukkan sejauh mana alat ukur yang kita gunakan dapat diandalkan atau dapat dipercaya (Singarimbun \& Effendi, 1989). Instrumen berupa kuesioner dikatakan andal jika Cronbach Alpha bernilai > 0,60. Guilford (1965) mengkategorikan uji reliabilitas menjadi 4 kategori berdasarkan hasil ujinya yaitu
a. 0,80-1,00 dengan kategori reliabilitas sangat tinggi
b. 0,60-0,80 dengan kategori reliabilitas tinggi
c. 0,40-0,60 dengan kategori reliabilitas sedang
d. 0,20-0,40 dengan kategori reliabilitas rendah

\subsubsection{Uji Matriks Korelasi Antar Variabel}

Langkah selanjutnya adalah menguji kelayakan perlu tidaknya analisis faktor dilakukan melalui pengujian Kaiser Mayer Olkin (KMO) Measure of Sampling Adequacy dan Bartlett Test of Sphericity. Kaiser Mayer Olkin (KMO) Measure of Sampling Adequacy adalah mengukur kecukupan sampling (sampling adequacy). Nilai ini membandingkan besarnya nilai koefisien korelasi yang diamati terhadap koefisien korelasi parsial. Nilai KMO yang kecil atau <0,5 menunjukkan bahwa korelasi antar pasangan variabel tidak bisa diterangkan oleh variabel lainnya dan analisis faktor tidak dapat dilakukan. Sedangkan Bartlett Test of Sphericity dilakukan untuk menguji apakah matriks korelasi adalah matriks identitas atau bukan. Layak atau tidaknya model faktor yaitu apabila nilai KMO $>0,5$ dan Bartlett Test of Sphericity <0,05 (Yamin \& Kurniawan, 2009).

Pengujian lain dilakukan dengan anti-image matrices correlation dengan melihat nilai Measure Sampling Adecuacy (MSA) untuk menilai kelayakan setiap variabel untuk dilakukan analisis faktor. Item pertanyaan atau variable dikatakan lolos uji jika nilai MSA $>0,5$. MSA digunakan untuk mengukur interkorelasi antarvariabel dan kesesuaian dari EFA yang dilakukan (Hair et al, 1998). Menurut Santoso (2017) nilai MSA dapat dikategorikan sebagai berikut :

a. $\mathrm{MSA}=1$ kategori variabel dapat diprediksi tanpa kesalahan dari variabel yang lain

b. MSA $\geq 0,5$, variabel masih bisa dianalisis lebih lanjut

c. MSA<0,5, variabel dieliminasi dan tidak disertakan dalam analisis faktor.

\subsubsection{Ekstraksi Faktor}

Tahapan berikutnya adalah menentukan banyaknya jumlah faktor yang terbentuk. Penentuan jumlah faktor dilakukan dengan mengekstraksi atau mereduksi sejumlah variabel menjadi sejumlah set variabel atau faktor baru yang lebih sedikit. Hair et all (1998) menyebutkan bahwa beberapa pendekatan yang dapat digunakan dalam menentukan sejumlah faktor yang terbentuk adalah dengan menggunakan pendekatan akar ciri, pendekatan persentase keragaman (eigenvalue) dan pendekatan scree test. Banyaknya jumlah faktor yang terbentuk dari penelitian ini akan ditentukan dengan pendekatan berdasarkan nilai persentase keragaman atau eigenvalue (jumlah varian yang dapat dijelaskan oleh setiap faktor) dan juga pendekatan scree test.

\subsubsection{Pendistribusian Variabel dan Rotasi Faktor}

Setelah terbentuk beberapa faktor, langkah selanjutnya adalah mendistribusikan 35 item pertanyaan ke dalam faktor-faktor baru tersebut berdasarkan loading factor-nya dengan menggunakan component matrix. Loading Factor menunjukkan tingkat keeratan variabel-variabel yang digunakan dengan faktor-faktor yang baru terbentuk. Semakin besar nilai loading factor dari suatu variabel, mengindikasikan bahwa variabel 
tersebut dapat dimasukkan ke dalam faktor yang terbentuk. Component matrix itu sendiri adalah komponen yang dipakai untuk mendistribusikan item-item pertanyaan yang telah diekstrak ke dalam faktor yang telah terbentuk berdasarkan bobotnya terhadap faktor yang terbentuk.

Agar semua variabel dapat mengisi ke dalam 6 faktor yang terbentuk secara optimum, diperlukan rotasi faktor. Rotasi faktor dilaksanakan sampai dengan struktur yang lebih sederhana terbentuk. Dua jenis metode untuk rotasi faktor yang paling sering digunakan adalah metode orthogonal dan oblique (Rummel, 1988). Model rotasi yang digunakan dalam penelitian ini adalah menggunakan metode orthogonal. Model rotasi ini menganggap bahwa faktor-faktor yang terbentuk merupakan faktor independen. Para ahli menyarankan penggunaan metode ini dikarenakan lebih menghasilkan struktur faktor yang lebih sederhana sehingga lebih mudah diintepretasikan daripada metode rotasi oblique (Johnson \& Wichern, 2002).

\subsubsection{Penamaan dan Pembahasan Faktor}

Setelah dilakukan rotasi matrik, selanjutnya dilakukan penamaan atas faktor yang terbentuk. Seluruh faktor baru yang terbentuk diberikan nama berdasarkan karakteristik yang mewakili variabel-variabel pembentuk faktor. Tahapan terakhir dari analisis faktor adalah melakukan pembahasan atas faktor-faktor yang terbentuk. Hal ini dilakukan untuk menjelaskan besarnya pengaruh faktor-faktor yang terbentuk terhadap permasalahan penyerapan anggaran satuan kerja di Provinsi Sumatera Barat.

\section{HASIL PENELITIAN}

\subsection{Data dan Uji Validitas}

Sebanyak 315 kuesioner disebar ke 315 satuan kerja di lingkup KPPN-KPPN yang ada di Provinsi Sumatera Barat yang dilaksanakan dalam periode waktu 1 Februari 2018 s.d. 15 Februari 2018. Penyebaran kuesioner dilakukan secara acak dan manual dengan bantuan dari pihak KPPN kepada para satuan kerja di wilayah bayar mereka. Dari 315 kuesioner yang disebar, sebanyak 213 kuesioner direspon dan dikembalikan. Dari 213 kuesioner yang dikembalikan, 13 kuesioner tidak diisi dengan lengkap sehingga dianggap tidak layak untuk dilakukan analisis lebih lanjut. Hal ini menyisakan 200 kuesioner yang siap dilakukan analisis faktor. Jumlah sampel sebanyak 200 sampel telah memenuhi batas minimal sampel yang dibutuhkan dalam melakukan analisis faktor yaitu sebanyak 5 kali dari jumlah item atau variabel yang digunakan dalam kuesioner atau sebanyak minimal 175 sampel ( 5 X 35 variabel).
Profil responden pada penelitian ini adalah sebagai berikut :

- Sebanyak 52,50\% atau 105 responden adalah laki-laki dan sebanyak 47,50\% atau 95 responden adalah perempuan

- Mayoritas responden telah bekerja di atas 5 tahun $(51 \%)$ dan hanya 14 responden $(7 \%)$ yang mempunyai pengalaman kerja di bawah 1 tahun

- Sebanyak 126 responden (63\%) memiliki background pendidikan minimal S1 dan sisanya memiliki Pendidikan s.d. DIII

- Dilihat dari jabatannya, sebanyak $44 \%$ responden menjabat sebagai Bendahara Pengeluaran, 26,50\% menjabat sebagai Pejabat Perbendaharaan Non Bendahara (KPA, PPK dan PPSPM) dan 29,50\% bekerja sebagai staff pengelola keuangan/operator satuan kerja

Adapun dari sisi sebaran responden dapat dilihat pada gambar di bawah.

Gambar 2. Sebaran Responden Penelitian

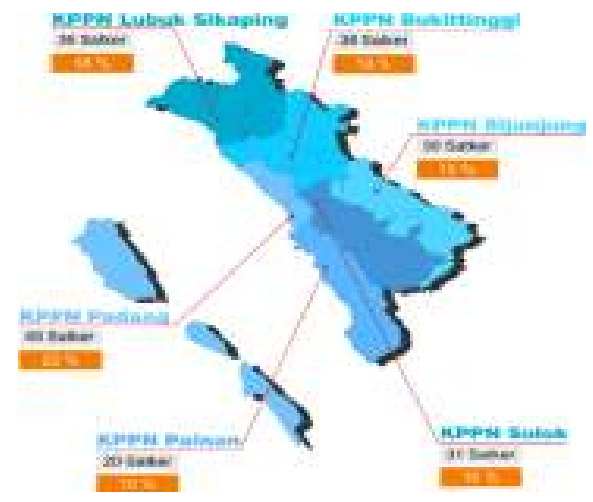

Berdasarkan tabel uji 2 arah maka didapatkan nilai $r$ tabel sebesar 0,1388. Hasil pengujian validitas dengan membandingkan nilai $r$ hitung untuk setiap item pertanyaan dengan $r$ tabel dapat dilihat pada tabel di bawah.

\begin{tabular}{|c|c|c|c|c|}
\hline $\mathbf{Q}$ & Item Pertanyaan & $\begin{array}{l}\text { Corrected } \\
\text { Item-Total } \\
\text { Correlation }\end{array}$ & $\begin{array}{c}\text { Nilai R } \\
\text { tabel }\end{array}$ & Ket \\
\hline 1 & $\begin{array}{lr}\text { Adanya } & \text { perubahan } \\
\text { kebijakan } & \text { Pemerintah, } \\
\text { seperti: } & \text { perubahan } \\
\text { nomenklatur dan struktur } \\
\text { organisasi K/L, kebijakan } \\
\text { pemotongan anggaran }\end{array}$ & 0,180 & 0,1388 & Valid \\
\hline 2 & $\begin{array}{ll}\text { Dokumen } & \text { anggaran/DIPA } \\
\text { terlambat diterima oleh } \\
\text { satker }\end{array}$ & 0,598 & 0,1388 & Valid \\
\hline 3 & $\begin{array}{l}\text { Belum adanya petunjuk } \\
\text { teknis (juknis) pelaksanaan } \\
\text { anggaran dari Eselon I K/L }\end{array}$ & 0,632 & 0,1388 & Valid \\
\hline 4 & $\begin{array}{l}\text { Anggaran kegiatan } \\
\text { diblokir/tanda bintang } \\
\text { karena belum ada data } \\
\text { pendukung atau harus ada } \\
\text { persetujuan terlebih dulu } \\
\text { dari DPR }\end{array}$ & 0,554 & 0,1388 & Valid \\
\hline
\end{tabular}




\begin{tabular}{|c|c|c|c|c|}
\hline 5 & $\begin{array}{l}\text { Satker salah dalam } \\
\text { penentuan akun } \\
\text { perlu revisi dokumen } \\
\text { anggaran (akun tidak sesuai } \\
\text { dengan peruntukannya) }\end{array}$ & 0,580 & 0,1388 & Valid \\
\hline 6 & $\begin{array}{lr}\text { Masa penyusunan dan } \\
\text { penelaahan anggaran yang } \\
\text { terlalu pendek sehingga } \\
\text { kesulitan } & \text { dalam } \\
\text { mempersiapkan } & \text { data } \\
\text { pendukung RKA KL } & \end{array}$ & 0,591 & 0,1388 & Valid \\
\hline 7 & $\begin{array}{l}\text { SK } \\
\text { penunjukkan/penggantian } \\
\text { pejabat perbendaharaan } \\
\text { (KPA, PPK, PPSPM, dan } \\
\text { Bendahara Pengeluaran) } \\
\text { terlambat ditetapkan }\end{array}$ & 0,650 & 0,1388 & Valid \\
\hline 8 & $\begin{array}{l}\text { SDM pelaksana pengadaan } \\
\text { barang dan jasa kurang } \\
\text { kompeten }\end{array}$ & 0,679 & 0,1388 & Valid \\
\hline 9 & $\begin{array}{l}\text { Rangkap tugas pejabat } \\
\text { perbendaharaan dalam } \\
\text { jabatan panitia Pengadaan } \\
\text { Barang dan Jasa }\end{array}$ & 0,620 & 0,1388 & Valid \\
\hline 10 & $\begin{array}{lr}\text { Ketakutan } & \text { Pejabat } \\
\text { Perbendaharaan } & \text { untuk } \\
\text { melaksanakan pengadaan } \\
\text { akibat pemberitaan } \\
\text { penangkapan } & \text { pejabat } \\
\text { dengan tuduhan korupsi }\end{array}$ & 0,523 & 0,1388 & Valid \\
\hline 11 & $\begin{array}{l}\text { Keengganan untuk menjadi } \\
\text { Pejabat Pengadaan karena } \\
\text { tidak seimbangnya risiko } \\
\text { pekerjaan dengan imbalan } \\
\text { yang diterima. }\end{array}$ & 0,516 & 0,1388 & Valid \\
\hline 12 & $\begin{array}{l}\text { Keterbatasan } \\
\text { pejabat/pelaksana } \\
\text { pengadaan barang/jasa } \\
\text { yang bersertifikat }\end{array}$ & 0,435 & 0,1388 & Valid \\
\hline 13 & $\begin{array}{l}\text { SK Panitia lelang terlambat } \\
\text { ditetapkan }\end{array}$ & 0,681 & 0,1388 & Valid \\
\hline 14 & $\begin{array}{ll}\text { Terlambat } & \text { dalam } \\
\text { penyusunanjadwal } & \\
\text { pelaksanaan lelang } & \end{array}$ & 0,720 & 0,1388 & Valid \\
\hline 15 & $\begin{array}{l}\text { Jadwal pelaksanaan lelang } \\
\text { yang disusun tidak realistis } \\
\text { atau tidak sesuai dengan } \\
\text { kebutuhan }\end{array}$ & 0,723 & 0,1388 & Valid \\
\hline 16 & $\begin{array}{lr}\text { Kesulitan } & \text { dalam } \\
\text { emnentukan Harga } & \\
\text { Perkiraan Sendiri (HPS) dan } \\
\text { HPS tidak ditentukan } \\
\text { berdasarkan keahlian dan } \\
\text { tidak melalui survey pasar }\end{array}$ & 0,706 & 0,1388 & Valid \\
\hline 17 & $\begin{array}{l}\text { Terlambat dalam } \\
\text { pengesahan dokumen } \\
\text { pengumuman lelang }\end{array}$ & 0,765 & 0,1388 & Valid \\
\hline 18 & $\begin{array}{l}\text { Proses lelang masih dalam } \\
\text { masa sanggah dan masih } \\
\text { menunggu proses hukum } \\
\text { sehingga tender harus } \\
\text { diulang }\end{array}$ & 0,634 & 0,1388 & Valid \\
\hline 19 & 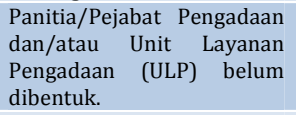 & 0,681 & 0,1388 & Valid \\
\hline 20 & $\begin{array}{lr}\text { Kontrak } & \text { belum } \\
\text { ditandatangani } & \text { karena } \\
\text { terdapat } & \text { berbagai } \\
\text { permasalahan seperti masih } \\
\text { menunggu persetujuan } \\
\text { lender (PPHLN) }\end{array}$ & 0,721 & 0,1388 & Valid \\
\hline 21 & $\begin{array}{ll}\text { Adanya revisi/addendum } \\
\text { kontrak sehingga } & \text { paket } \\
\text { pekerjaan } & \text { perlu } \\
\text { disesuaikan. } & \end{array}$ & 0,586 & 0,1388 & Valid \\
\hline 22 & $\begin{array}{l}\text { Terdapat permasalahan } \\
\text { terkait pembebasan tanah, } \\
\text { seperti pembentukan } \\
\text { panitia pembebasan tanah } \\
\text { terlambat ditetapkan, } \\
\text { alokasi dana untuk } \\
\text { pembebasan tanah tidak } \\
\text { mencukupi, resum } \\
\text { mencapai kesepakatan }\end{array}$ & 0,601 & 0,1388 & Valid \\
\hline
\end{tabular}

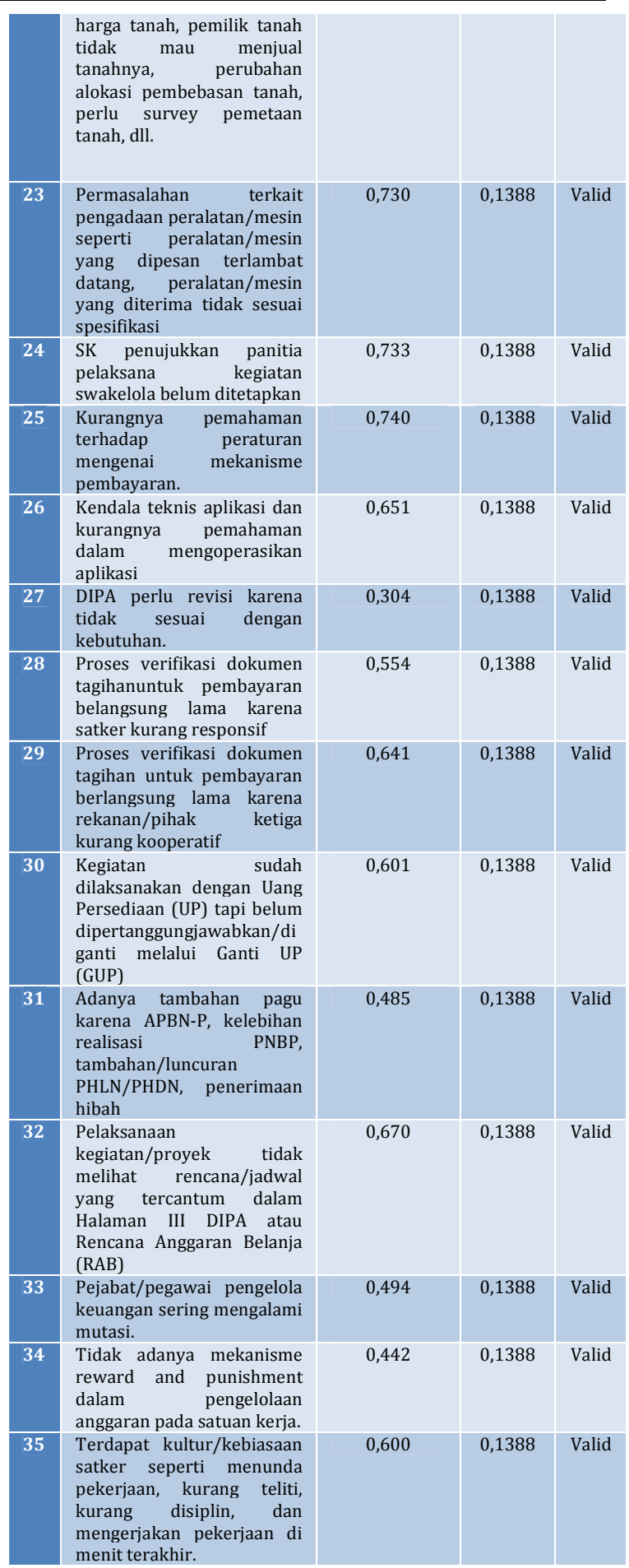

Sumber : Output SPSS 22, diolah

Hasil uji validitas terhadap item-item pertanyaan sebagaimana tersaji pada tabel di atas menunjukkan bahwa keseluruhan item pertanyaan dinyatakan valid karena nilai $r$ hitung $>0,1388$. Oleh karena itu, semua item pertanyaan diikutkan dalam uji berikutnya yaitu uji reliabilitas. 


\subsection{Uji Reliabilitas}

Hasil uji reliabilitas data terhadap 35 pertanyaan valid yang dilakukan menggunakan SPSS.22 dapat dilihat pada tabel 2 di bawah

Tabel 2. Hasil Ujji Reliabilitas

\begin{tabular}{|l|l|l|}
$\begin{array}{l}\text { Cronbach's } \\
\text { Alpha }\end{array}$ & $\begin{array}{l}\text { Cronbach's Alpha Based on } \\
\text { Standardized Items }\end{array}$ & $\begin{array}{l}\text { N of } \\
\text { Items }\end{array}$ \\
$\mathbf{0 , 9 5 4}$ & 0,955 & 35 \\
\hline
\end{tabular}

Sumber : Output SPSS 22, diolah

Hasil pengujian reliabilitas tersebut menunjukkan bahwa nilai Cronbach Alpha adalah sebesar 0,954 $(>0,6)$ dan dapat disimpulkan instrumen yang digunakan sudah andal (reliable) dengan kategori realibilitas sangat tinggi $>0,8$

\subsection{Uji Korelasi Antar Variabel}

Dari hasil pengujian terhadap 35 item pertanyaan, dihasilkan nilai KMO Measure of Sampling Adequacy adalah sebesar 0,929 (>0,5) dan Bartlett Test of Sphericity sebesar $0,0000(<0,05)$ sehingga layak untuk dilakukan analisis faktor lebih lanjut. Hasil pengujian tersaji pada tabel 3 di bawah.
Tabel 3. Hasil Uji Korelasi

\begin{tabular}{|l|r|r|}
\hline $\begin{array}{l}\text { Kaiser-Meyer-Olkin Measure of } \\
\text { Sampling Adequacy. }\end{array}$ & $\mathbf{0 , 9 2 9}$ \\
\hline $\begin{array}{l}\text { Bartlett's Test of } \\
\text { Sphericity }\end{array}$ & Approx. Chi-Square & 4444,990 \\
\cline { 2 - 3 } & df & 595 \\
\hline & Sig. & 0,000 \\
\hline
\end{tabular}

Sumber : Output SPSS 22, diolah

Pengujian lain dilakukan dengan anti-image matrices correlation dengan melihat nilai Measure Sampling Adecuacy (MSA). Dari hasil pengujian terhadap 35 item, semuanya lolos uji karena memiliki nilai MSA >0,5 sebagaimana tercantum pada tabel 4 di bawah.

Tabel 4. Hasil Uji Anti-Image Matrices Correlation

\begin{tabular}{|c|c|c|c|c|c|c|c|c|c|}
\hline Q1 & Q2 & Q3 & Q4 & Q5 & Q6 & Q7 & Q8 & Q9 & Q10 \\
\hline $0,686^{a}$ & $0,903^{\mathrm{a}}$ & $0,905^{a}$ & $0,931^{a}$ & $0,916^{a}$ & $0,940^{a}$ & $0,939^{a}$ & $0,944^{a}$ & $0,936^{a}$ & $0,887^{a}$ \\
\hline Q11 & Q12 & Q13 & Q14 & Q15 & Q16 & Q17 & Q18 & Q19 & Q20 \\
\hline $0,870^{a}$ & $0,906^{a}$ & $0,928^{a}$ & $0,931^{\mathrm{a}}$ & $0,952^{\mathrm{a}}$ & $0,960^{a}$ & $0,964^{\mathrm{a}}$ & $0,957^{a}$ & $0,939^{a}$ & $0,956^{a}$ \\
\hline Q21 & Q22 & Q23 & Q24 & Q25 & Q26 & Q27 & Q28 & Q29 & Q30 \\
\hline $0,913^{a}$ & $0,926^{a}$ & $0,947^{a}$ & $0,954^{a}$ & $0,931^{a}$ & $0,907^{a}$ & $0,809^{a}$ & $0,920^{a}$ & $0,929^{a}$ & $0,937^{a}$ \\
\hline Q21 & Q32 & Q33 & Q34 & Q35 & & & & & \\
\hline $0,894^{a}$ & $0,930^{a}$ & $0,945^{a}$ & $0,901^{a}$ & $0,915^{\mathrm{a}}$ & & & & & \\
\hline
\end{tabular}

\subsection{Penentuan Jumlah Faktor}

Penentuan jumlah faktor pada penelitian ini dilakukan dengan dua cara yaitu dengan mengintepretasikan Scree Plot yang dihasilkan dari output SPSS.22 dan dengan menggunakan pendekatan persentase keragaman (eigenvalue).
Adapun gambar scree plot yang dihasilkan dari output SPSS.22 adalah sebagaimana gambar di bawah :

Gambar 3. Scree Plot 


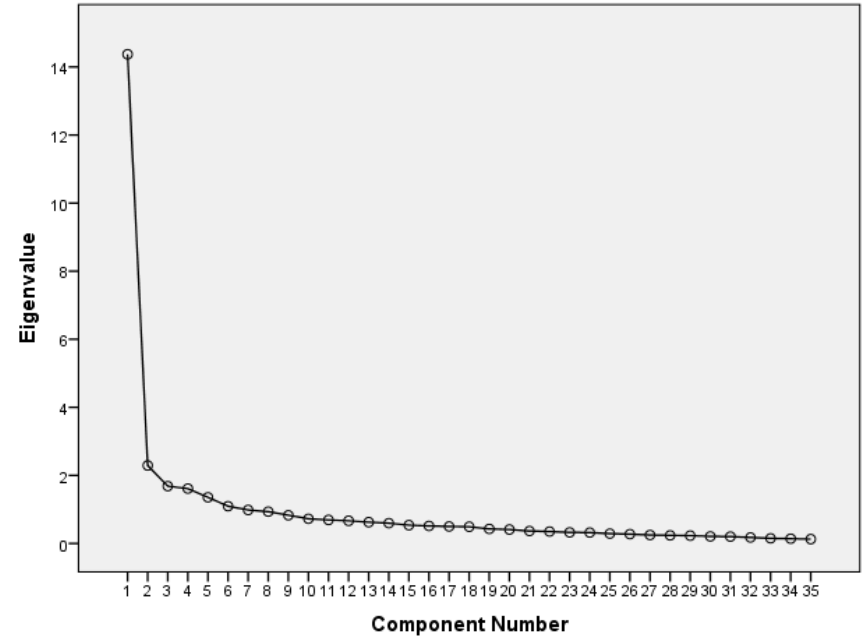

Sumber : Output SPSS 22

Gambar Scree Plot di atas menunjukkan relasi antara faktor atau variabel dengan nilai eigennya. Proses ekstraksi faktor berhenti ketika kurva atau garis menjadi relatif lebih landai. Dari gambar di atas terlihat bahwa kurva menunjukkan arah yang mulai melandai pada saat 6 komponen terbentuk. Hal ini mengindikasikan bahwa 6 komponen atau faktor merupakan jumlah ideal faktor dominan yang ideal menjadi penyebab permasalahan yang dianalisis.

Cara yang kedua adalah dengan menggunakan pendekatan persentase keragaman atau Eigenvalue. Jumlah faktor ditentukan dari jumlah variabel yang mendapatkan nilai Eigenvalue $>1$ setelah dilakukan ekstraksi faktor. Dari hasil ekstraksi yang dilakukan terbentuk 6 faktor yang optimal dengan nilai eigenvalue lebih dari 1 dengan persentase varian sebesar 64,034\% sebagai berikut : a. Faktor pertama memiliki eigenvalue sebesar 14,373 yang dapat menjelaskan variasi seluruh item sebesar $41.065 \%$.

b. Faktor kedua memiliki eigenvalue sebesar 2,292 yang dapat menjelaskan variasi seluruh item sebesar 6,548\%.

c. Faktor ketiga memiliki eigenvalue sebesar 1,685 yang dapat menjelaskan variasi seluruh item sebesar $4,815 \%$.

d. Faktor keempat memiliki eigenvalue sebesar 1,611 yang dapat menjelaskan variasi seluruh item sebesar 4,602\%.

e. Faktor kelima memiliki eigenvalue sebesar 1,356 yang dapat menjelaskan variasi seluruh item sebesar 3,875\%.

f. Faktor keenam memiliki eigenvalue sebesar 1,095 yang dapat menjelaskan variasi seluruh item sebesar 3,129\%.

Hasil ekstraksi yang menunjukkan nilai eigenvalue setiap faktor pada output SPSS 22 yang digunakan tersaji pada tabel 5 berikut.

Tabel 5. Hasil Ekstraksi Faktor

\begin{tabular}{|c|c|c|c|c|c|c|c|c|c|}
\hline \multirow[t]{2}{*}{$\mathbf{Q}$} & \multicolumn{3}{|c|}{ Initial Eigenvalues } & \multicolumn{3}{|c|}{$\begin{array}{l}\text { Extraction Sums of Squared } \\
\text { Loadings }\end{array}$} & \multicolumn{3}{|c|}{$\begin{array}{c}\text { Rotation Sums of Squared } \\
\text { Loadings }\end{array}$} \\
\hline & Total & $\begin{array}{c}\% \text { of } \\
\text { Variance }\end{array}$ & $\begin{array}{c}\text { Cumulative } \\
\%\end{array}$ & Total & $\begin{array}{c}\% \text { of } \\
\text { Variance }\end{array}$ & $\begin{array}{c}\text { Cumulative } \\
\%\end{array}$ & Total & $\begin{array}{c}\% \text { of } \\
\text { Variance }\end{array}$ & $\begin{array}{c}\text { Cumulative } \\
\%\end{array}$ \\
\hline 1 & 14,373 & 41,065 & 41,065 & 14,373 & 41,065 & 41,065 & 6,474 & 18,497 & 18,497 \\
\hline 2 & 2,292 & 6,548 & 47,613 & 2,292 & 6,548 & 47,613 & 4,331 & 12,373 & 30,870 \\
\hline 3 & 1,685 & 4,815 & 52,428 & 1,685 & 4,815 & 52,428 & 3,865 & 11,044 & 41,914 \\
\hline 4 & 1,611 & 4,602 & 57,030 & 1,611 & 4,602 & 57,030 & 2,756 & 7,873 & 49,787 \\
\hline 5 & 1,356 & 3,875 & 60,905 & 1,356 & 3,875 & 60,905 & 2,578 & 7,367 & 57,154 \\
\hline 6 & 1,095 & 3,129 & 64,034 & 1,095 & 3,129 & 64,034 & 2,408 & 6,880 & 64,034 \\
\hline 7 & ,984 & 2,810 & 66,844 & & & & & & \\
\hline 8 & ,935 & 2,670 & 69,515 & & & & & & \\
\hline 9 & ,830 & 2,370 & 71,885 & & & & & & \\
\hline
\end{tabular}




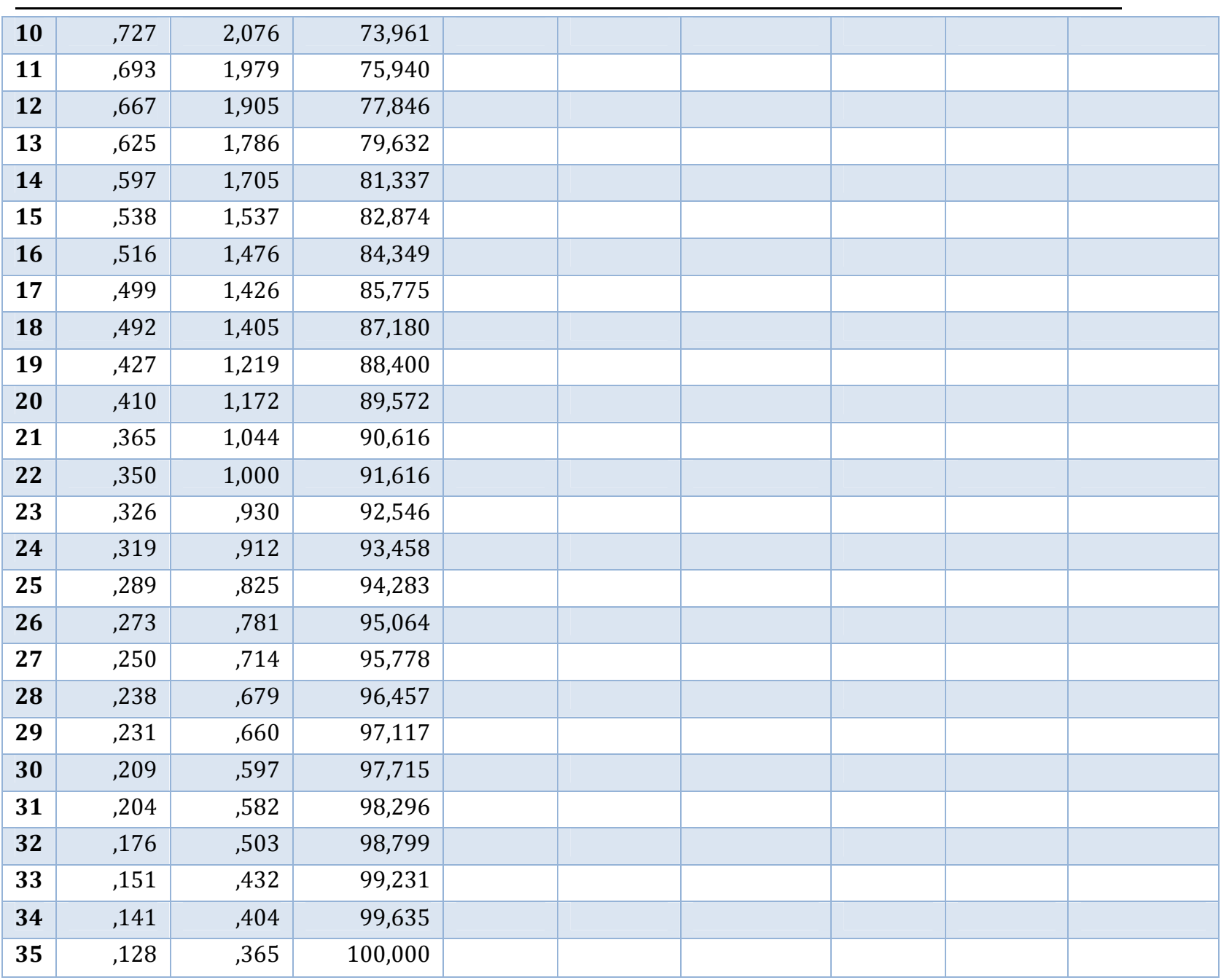

Sumber : Output SPSS 22

\subsection{Pendistribusian Variabel Dalam Faktor dan Rotasi Faktor}

Setelah terbentuk 6 faktor, langkah selanjutnya adalah mendistribusikan 35 item pertanyaan ke dalam 6 faktor tersebut berdasarkan loading factor-nya dengan menggunakan component matrix. Sebagaimana tersaji pada tabel 6 dapat disimpulkan bahwa semua item pertanyaan yang sangat kuat masuk ke dalam faktor 1, sedangkan banyaknya jumlah faktor yang terbentuk sebanyak 6 faktor. Agar semua variabel dapat mengisi ke dalam 6 faktor yang terbentuk secara optimum dan faktor matriks terlihat lebih sederhana diperlukan rotasi faktor dengan menggunakan metode rotasi orthogonal. Hasil rotasi faktor terlihat pada tabel 7 dibawah.

Tabel 6. Component Matrix

\begin{tabular}{|c|c|c|c|c|c|c|}
\hline & \multicolumn{7}{c|}{ Component } \\
\hline & 1 & 2 & 3 & 4 & 5 & 6 \\
\hline $\mathbf{Q 1 7}$ & $\mathbf{0 , 7 9 7}$ & $-0,182$ & $-0,141$ & 0,002 & $-0,066$ & $-0,133$ \\
\hline $\mathbf{Q 2 5}$ & $\mathbf{0 , 7 7 3}$ & $-0,034$ & $-0,130$ & 0,120 & $-0,265$ & 0,088 \\
\hline $\mathbf{Q 2 4}$ & $\mathbf{0 , 7 6 8}$ & 0,018 & $-0,126$ & 0,088 & $-0,241$ & $-0,184$ \\
\hline $\mathbf{Q 1 4}$ & $\mathbf{0 , 7 6 1}$ & $-0,222$ & $-0,312$ & 0,069 & 0,045 & $-0,148$ \\
\hline $\mathbf{Q 2 3}$ & $\mathbf{0 , 7 6 0}$ & 0,159 & $-0,020$ & 0,164 & $-0,025$ & $-0,038$ \\
\hline $\mathbf{Q 2 0}$ & $\mathbf{0 , 7 5 1}$ & 0,210 & $-0,032$ & $-0,065$ & 0,084 & $-0,334$ \\
\hline $\mathbf{Q 1 5}$ & $\mathbf{0 , 7 5 1}$ & $-0,191$ & $-0,071$ & 0,131 & 0,005 & $-0,131$ \\
\hline $\mathbf{Q 1 6}$ & $\mathbf{0 , 7 3 2}$ & 0,082 & 0,023 & 0,056 & 0,209 & $-0,095$ \\
\hline $\mathbf{Q 1 3}$ & $\mathbf{0 , 7 1 9}$ & $-0,186$ & $-0,252$ & 0,030 & $-0,020$ & $-0,119$ \\
\hline
\end{tabular}




\begin{tabular}{|l|l|l|l|l|l|l|}
\hline $\mathbf{Q 1 9}$ & $\mathbf{0 , 7 1 5}$ & $-0,034$ & $-0,075$ & 0,124 & $-0,290$ & $-0,219$ \\
\hline $\mathbf{Q 0 8}$ & $\mathbf{0 , 6 9 8}$ & $-0,310$ & 0,006 & 0,050 & 0,090 & 0,049 \\
\hline $\mathbf{Q 3 2}$ & $\mathbf{0 , 6 9 1}$ & $\mathbf{0 , 1 2 5}$ & 0,187 & 0,026 & 0,138 & 0,136 \\
\hline $\mathbf{Q 2 6}$ & $\mathbf{0 , 6 8 6}$ & 0,123 & $-0,129$ & 0,095 & $-0,289$ & 0,140 \\
\hline $\mathbf{Q 0 7}$ & $\mathbf{0 , 6 7 4}$ & $-0,185$ & 0,093 & $-0,381$ & $-0,104$ & $-0,019$ \\
\hline $\mathbf{Q 2 9}$ & $\mathbf{0 , 6 7 3}$ & $\mathbf{0 , 1 8 1}$ & $-0,177$ & 0,103 & $-0,037$ & 0,312 \\
\hline $\mathbf{Q 1 8}$ & $\mathbf{0 , 6 7 1}$ & 0,371 & 0,010 & $-0,008$ & $-0,036$ & $-0,302$ \\
\hline $\mathbf{Q 0 3}$ & $\mathbf{0 , 6 5 7}$ & $-0,295$ & 0,041 & $-0,260$ & $-0,226$ & $-0,062$ \\
\hline $\mathbf{Q 0 9}$ & $\mathbf{0 , 6 5 2}$ & $-0,248$ & $-0,190$ & 0,047 & 0,045 & 0,048 \\
\hline $\mathbf{Q 2 2}$ & $\mathbf{0 , 6 3 2}$ & 0,399 & 0,085 & $-0,067$ & 0,121 & $-0,225$ \\
\hline $\mathbf{Q 0 2}$ & $\mathbf{0 , 6 3 0}$ & $-0,369$ & $-0,100$ & $-0,392$ & $-0,138$ & 0,068 \\
\hline $\mathbf{Q 3 0}$ & $\mathbf{0 , 6 2 5}$ & 0,371 & 0,205 & 0,003 & $-0,067$ & 0,115 \\
\hline $\mathbf{Q 0 6}$ & $\mathbf{0 , 6 1 7}$ & $-0,212$ & $-0,044$ & $-0,311$ & 0,128 & 0,285 \\
\hline $\mathbf{Q 2 1}$ & $\mathbf{0 , 6 1 6}$ & 0,420 & 0,064 & $-0,237$ & 0,204 & $-0,129$ \\
\hline $\mathbf{Q 3 5}$ & $\mathbf{0 , 6 1 2}$ & $-0,199$ & 0,344 & 0,360 & 0,010 & 0,167 \\
\hline $\mathbf{Q 0 5}$ & $\mathbf{0 , 6 1 1}$ & $-0,081$ & $-0,016$ & $-0,462$ & 0,280 & 0,261 \\
\hline $\mathbf{Q 2 8}$ & $\mathbf{0 , 5 9 4}$ & 0,318 & $-0,211$ & 0,070 & $-0,290$ & 0,291 \\
\hline $\mathbf{Q 0 4}$ & $\mathbf{0 , 5 7 0}$ & $-0,223$ & 0,274 & $-0,407$ & 0,076 & 0,046 \\
\hline $\mathbf{Q 1 1}$ & $\mathbf{0 , 5 4 7}$ & 0,257 & $-0,191$ & 0,161 & 0,482 & 0,166 \\
\hline $\mathbf{Q 1 0}$ & $\mathbf{0 , 5 4 7}$ & $-0,016$ & 0,009 & 0,086 & 0,518 & 0,001 \\
\hline $\mathbf{Q 3 3}$ & $\mathbf{0 , 5 1 0}$ & $-0,193$ & 0,448 & 0,182 & $-0,051$ & 0,048 \\
\hline $\mathbf{Q 1 2}$ & $\mathbf{0 , 4 6 3}$ & $-0,145$ & $-0,141$ & 0,425 & 0,237 & 0,115 \\
\hline $\mathbf{Q 3 4}$ & $\mathbf{0 , 4 5 6}$ & $-0,322$ & 0,370 & 0,436 & $-0,006$ & 0,045 \\
\hline $\mathbf{Q 3 1}$ & $\mathbf{0 , 5 1 4}$ & 0,580 & 0,249 & $-0,132$ & $-0,085$ & $-0,019$ \\
\hline $\mathbf{Q 0 1}$ & $\mathbf{0 , 1 7 9}$ & $-0,247$ & 0,660 & 0,002 & 0,057 & $-0,258$ \\
\hline & $\mathbf{0 , 3 1 7}$ & 0,321 & 0,368 & $-0,013$ & $-0,273$ & 0,342 \\
\hline & & & & & \\
\hline $\mathbf{Q 2 7}$ & & & & \\
\hline
\end{tabular}

Sumber : Output SPSS 22

Tabel 7. Rotated Component Matrix

\begin{tabular}{|c|c|c|c|c|c|c|}
\hline & \multicolumn{6}{|c|}{ Component } \\
\hline & 1 & 2 & 3 & 4 & 5 & 6 \\
\hline Q14 & 0,72 & 0,18 & 0,29 & 0,34 & 0,06 & $-0,03$ \\
\hline Q24 & 0,71 & 0,35 & 0,15 & 0,07 & 0,13 & 0,20 \\
\hline Q19 & 0,70 & 0,30 & 0,11 & 0,01 & 0,20 & 0,17 \\
\hline Q17 & 0,68 & 0,25 & 0,34 & 0,20 & 0,16 & 0,07 \\
\hline Q13 & 0,67 & 0,18 & 0,29 & 0,25 & 0,07 & 0,02 \\
\hline Q25 & 0,66 & 0,18 & 0,22 & 0,16 & 0,14 & 0,39 \\
\hline Q15 & 0,62 & 0,22 & 0,24 & 0,27 & 0,26 & 0,04 \\
\hline Q26 & 0,55 & 0,22 & 0,15 & 0,12 & 0,05 & 0,47 \\
\hline Q09 & 0,54 & 0,06 & 0,33 & 0,33 & 0,11 & 0,08 \\
\hline Q23 & 0,50 & 0,42 & 0,11 & 0,29 & 0,19 & 0,28 \\
\hline Q08 & 0,48 & 0,08 & 0,39 & 0,33 & 0,31 & 0,06 \\
\hline Q21 & 0,13 & 0,72 & 0,28 & 0,20 & $-0,02$ & 0,14 \\
\hline Q22 & 0,24 & 0,71 & 0,12 & 0,18 & 0,08 & 0,13 \\
\hline Q31 & 0,05 & 0,70 & 0,10 & $-0,01$ & 0,08 & 0,42 \\
\hline Q18 & 0,41 & 0,69 & 0,06 & 0,09 & 0,07 & 0,15 \\
\hline $\mathbf{Q 2 0}$ & 0,47 & 0,65 & 0,20 & 0,18 & 0,09 & 0,01 \\
\hline Q30 & 0,18 & 0,51 & 0,15 & 0,14 & 0,19 & 0,46 \\
\hline Q16 & 0,38 & 0,46 & 0,24 & 0,38 & 0,21 & 0,08 \\
\hline Q32 & 0,21 & 0,39 & 0,29 & 0,34 & 0,28 & 0,30 \\
\hline $\mathbf{Q 0 5}$ & 0,10 & 0,24 & 0,75 & 0,31 & $-0,02$ & 0,13 \\
\hline Q02 & 0,48 & 0,03 & 0,69 & $-0,01$ & 0,06 & 0,07 \\
\hline Q04 & 0,15 & 0,23 & 0,68 & 0,02 & 0,30 & 0,04 \\
\hline Q06 & 0,24 & 0,08 & 0,67 & 0,28 & 0,06 & 0,18 \\
\hline
\end{tabular}




\begin{tabular}{|c|c|c|c|c|c|c|}
\hline $\mathbf{Q 0 7}$ & 0,38 & 0,26 & 0,63 & $-0,04$ & 0,17 & 0,11 \\
\hline $\mathbf{Q 0 3}$ & 0,52 & 0,14 & 0,54 & $-0,09$ & 0,22 & 0,09 \\
\hline $\mathbf{Q 1 1}$ & 0,14 & 0,36 & 0,10 & 0,71 & $-0,06$ & 0,15 \\
\hline $\mathbf{Q 1 0}$ & 0,15 & 0,31 & 0,24 & 0,60 & 0,19 & $-0,08$ \\
\hline $\mathbf{Q 1 2}$ & 0,36 & $-0,02$ & $-0,02$ & 0,57 & 0,20 & 0,08 \\
\hline $\mathbf{Q 0 1}$ & $-0,06$ & 0,18 & 0,15 & $-0,15$ & 0,69 & $-0,19$ \\
\hline $\mathbf{Q 3 4}$ & 0,30 & $-0,05$ & 0,02 & 0,24 & 0,69 & 0,12 \\
\hline $\mathbf{Q 3 3}$ & 0,21 & 0,12 & 0,19 & 0,10 & 0,63 & 0,19 \\
\hline $\mathbf{Q 3 5}$ & 0,31 & 0,06 & 0,13 & 0,32 & 0,63 & 0,28 \\
\hline $\mathbf{Q 2 7}$ & $-0,06$ & 0,24 & 0,10 & $-0,08$ & 0,23 & 0,63 \\
\hline $\mathbf{Q 2 8}$ & 0,42 & 0,24 & 0,10 & 0,15 & $-0,13$ & 0,63 \\
\hline $\mathbf{Q 2 9}$ & 0,39 & 0,22 & 0,20 & 0,38 & $-0,02$ & 0,49 \\
\hline \multicolumn{7}{|c|}{} \\
\hline
\end{tabular}

Sumber : Output SPSS 22

\subsection{Penamaan Faktor yang Terbentuk}

Untuk memberikan nama pada faktor yang terbentuk dari hasil rotasi matrik, keenam faktor diberikan nama sesuai dengan karakteristik itemitem pertanyaan atau variabel yang membentuknya. Tidak terdapat standar atau acuan yang baku dalam penamaan faktor. Untuk itu dalam memberikan nama faktor yang terbentuk dibutuhkan justifikasi yang tepat berdasarkan karakteristik variabel yang ada. Adapun setelah melihat karakteristik variabel yang membentuknya, penulis memberikan nama keenam faktor tersebut dengan nama yang dapat dilihat pada tabel di bawah.

Tabel 8. Penamaan Faktor Yang Terbentuk

\begin{tabular}{|c|c|c|c|c|}
\hline Nama Faktor & $\begin{array}{l}\text { Eigen } \\
\text { Value/ } \\
\text { Total } \\
\text { Variance }\end{array}$ & & Item Pertanyaan & $\begin{array}{l}\text { Factor } \\
\text { Loading }\end{array}$ \\
\hline Faktor 1 & \multirow{11}{*}{$\begin{array}{l}14,373 / \\
41,065 \%\end{array}$} & Q14 & Terlambat dalam penyusunanjadwal pelaksanaan lelang & 0,72 \\
\hline \multirow{10}{*}{$\begin{array}{l}\text { Proses Lelang } \\
\text { Pengadaan Barang } \\
\text { dan Jasa }\end{array}$} & & Q24 & $\begin{array}{l}\text { SK penujukkan panitia pelaksana kegiatan swakelola } \\
\text { belum ditetapkan }\end{array}$ & 0,71 \\
\hline & & Q19 & $\begin{array}{l}\text { Panitia/Pejabat Pengadaan dan/atau Unit Layanan } \\
\text { Pengadaan (ULP) belum dibentuk. }\end{array}$ & 0,70 \\
\hline & & Q17 & $\begin{array}{l}\text { Terlambat dalam pengesahan dokumen pengumuman } \\
\text { lelang }\end{array}$ & 0,68 \\
\hline & & Q13 & SK Panitia lelang terlambat ditetapkan & 0,67 \\
\hline & & Q25 & $\begin{array}{l}\text { Kurangnya pemahaman terhadap peraturan mengenai } \\
\text { mekanisme pembayaran. }\end{array}$ & 0,66 \\
\hline & & Q15 & $\begin{array}{l}\text { Jadwal pelaksanaan lelang yang disusun tidak realistis } \\
\text { atau tidak sesuai dengan kebutuhan }\end{array}$ & 0,62 \\
\hline & & Q26 & $\begin{array}{l}\text { Kendala teknis aplikasi dan kurangnya pemahaman dalam } \\
\text { mengoperasikan aplikasi }\end{array}$ & 0,55 \\
\hline & & Q09 & $\begin{array}{l}\text { Rangkap tugas pejabat perbendaharaan dalam jabatan } \\
\text { panitia Pengadaan Barang dan Jasa }\end{array}$ & 0,54 \\
\hline & & Q23 & $\begin{array}{l}\text { Permasalahan terkait pengadaan peralatan/mesin seperti } \\
\text { peralatan/mesin yang dipesan terlambat datang, } \\
\text { peralatan/mesin yang diterima tidak sesuai spesifikasi }\end{array}$ & 0,50 \\
\hline & & Q8 & $\begin{array}{l}\text { SDM pelaksana pengadaan barang dan jasa kurang } \\
\text { kompeten }\end{array}$ & 0,48 \\
\hline Faktor 2 & $2,292 /$ & Q21 & $\begin{array}{l}\text { Adanya revisi/addendum kontrak sehingga paket } \\
\text { pekerjaan perlu disesuaikan. }\end{array}$ & 0,72 \\
\hline
\end{tabular}




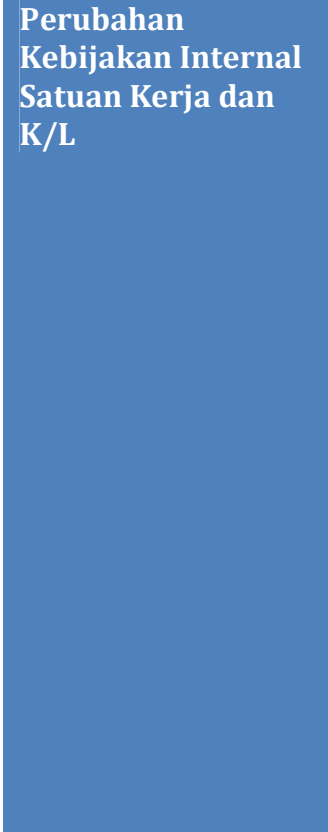

Faktor 3

\section{Administrasi}

Perencanaan

anggaran

Faktor 4

Pejabat

Perbendaharaan

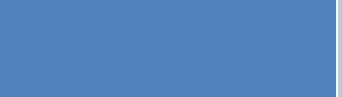

Faktor 5

\section{Perubahan}

Kebijakan

Pemerintah

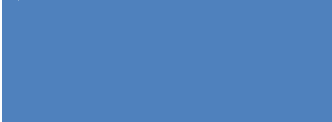

\section{Faktor 6}

Proses Verifikasi

Dokumen untuk

Pelaksanaan

Anggaran

$6,548 \%$

Q22 Terdapat permasalahan terkait pembebasan tanah, seperti

0,71 pembentukan panitia pembebasan tanah terlambat ditetapkan, alokasi dana untuk pembebasan tanah tidak mencukupi, belum mencapai kesepakatan harga tanah, pemilik tanah tidak mau menjual tanahnya, perubahan alokasi pembebasan tanah, perlu survey pemetaan tanah, dll.

Q31 Adanya tambahan pagu karena APBN-P, kelebihan realisasi PNBP, tambahan/luncuran PHLN/PHDN, penerimaan hibah

\begin{tabular}{l|l|l} 
Q18 Proses lelang masih dalam masa sanggah dan masih & 0,69
\end{tabular} menunggu proses hukum sehingga tender harus diulang

Q20 Kontrak belum ditandatangani karena terdapat berbagai $\quad 0,65$ permasalahan seperti masih menunggu persetujuan lender (PPHLN)

Q30 Kegiatan sudah dilaksanakan dengan Uang Persediaan (UP) tapi belum dipertanggungjawabkan/diganti melalui Ganti UP (GUP)

Q16 Kesulitan dalam emnentukan Harga Perkiraan Sendiri (HPS) dan HPS tidak ditentukan berdasarkan keahlian dan tidak melalui survey pasar

\begin{tabular}{l|l|l|}
\hline Q32 Pelaksanaan kegiatan/proyek tidak melihat & 0,39
\end{tabular} rencana/jadwal yang tercantum dalam Halaman III DIPA atau Rencana Anggaran Belanja (RAB)

$1,685 /$

$4,815 \%$

Q05 Satker salah dalam penentuan akun sehingga perlu revisi dokumen anggaran (akun tidak sesuai dengan peruntukannya)

Q02 Dokumen anggaran/DIPA terlambat diterima oleh satker

Q04 Anggaran kegiatan diblokir/tanda bintang karena belum ada data pendukung atau harus ada persetujuan terlebih dulu dari DPR

Q06 Masa penyusunan dan penelaahan anggaran yang terlalu pendek sehingga kesulitan dalam mempersiapkan data pendukung RKA KL

Q07 SK penunjukkan/penggantian pejabat perbendaharaan (KPA, PPK, PPSPM, dan Bendahara Pengeluaran) terlambat ditetapkan

Q03 Belum adanya petunjuk teknis (juknis) pelaksanaan anggaran dari Eselon I K/L
$1,611 /$

$4,602 \%$

$1,356 /$ $3,875 \%$

$1,095 /$ $3,129 \%$
Q11 Keengganan untuk menjadi Pejabat Pengadaan karena

tidak seimbangnya risiko pekerjaan dengan imbalan yang diterima.

Q10 Ketakutan Pejabat Perbendaharaan untuk melaksanakan pengadaan akibat pemberitaan penangkapan pejabat dengan tuduhan korupsi

Q12 Keterbatasan pejabat/pelaksana pengadaan barang/jasa yang bersertifikat

Q01 Adanya perubahan kebijakan Pemerintah, seperti: perubahan nomenklatur dan struktur organisasi K/L, kebijakan pemotongan anggaran

\begin{tabular}{l|l|l} 
Q34 Tidak adanya mekanisme reward and punishment dalam & 0,69
\end{tabular} pengelolaan anggaran pada satuan kerja.

Pejabat/pegawai pengelola keuangan sering mengalami mutasi.

Q35 Terdapat kultur/kebiasaan satker seperti menunda pekerjaan, kurang teliti, kurang disiplin, dan mengerjakan pekerjaan di menit terakhir.

\begin{tabular}{|l|l|l|l|}
\hline Q27 DIPA perlu revisi karena tidak sesuai dengan kebutuhan. & 0,63
\end{tabular}

Q28 Proses verifikasi dokumen tagihanuntuk pembayaran belangsung lama karena satker kurang responsif

Q29 Proses verifikasi dokumen tagihan untuk pembayaran berlangsung lama karena rekanan/pihak ketiga kurang 


\subsection{Pembahasan Faktor}

Berdasarkan analisis faktor, permasalahan penyerapan anggaran pada satuan kerja lingkup Kanwil DJPb Provinsi Sumatera Barat dapat diterangkan dengan 6 faktor dengan variansi sebesar 64,034\%. Sedangkan sisanya sebesar $35,966 \%$ disebabkan oleh faktor faktor yang lain yang tidak termasuk dalam penelitian yang dilakukan. Adapun pembahasan keenam faktor yang terbentuk adalah sebagai berikut:

\section{Faktor Proses Lelang dan Pengadaan Barang dan Jasa.}

Faktor proses lelang pengadaan barang dan jasa yang menjelaskan seluruh item sebesar $41,065 \%$ merupakan faktor yang paling dominan penyebab terjadinya penumpukan penyerapan anggaran pada akhir tahun anggaran di wilayah Provinsi Sumatera Barat. Berbagai permasalahan terkait dengan terlambatnya penyusunan jadwal lelang, SK Panitia lelang dan pengesahan dokumen lelang ditenggarai sebagai faktor penyebab utama keterlambatan penyerapan anggaran yang pada akhirnya menjadi penyebab menumpuknya tagihan pada akhir tahun anggaran 2017. Selain itu, masih kurangnya SDM yang berkompeten dan memiliki sertifikat pengadaan barang dan jasa, juga termasuk ke dalam variabel faktor yang paling dominan menyebabkan keterlambatan penyerapan anggaran di wilayah Provinsi Sumatera Barat.

Apabila dihubungkan dengan komposisi realisasi belanja TA 2017, jumlah realisasi belanja yang dikontrakkan ke pihak penyedia barang/jasa mencapai $\mathrm{Rp} \mathrm{2,75}$ triliun atau mencapai 47,03\% dari jumlah keseluruhan realisasi belanja barang, belanja modal dan belanja bantuan sosial di Sumatera Barat (tabel 9). Bahkan untuk komponen belanja modal, lebih dari $82 \%$ nilai realisasi tahun 2017 terkait langsung dengan proses lelang dan pengadaan barang dan jasa. Besarnya komposisi belanja yang dikontrakkan ke pihak penyedia barang dan jasa tersebut mengkonfirmasi kenapa faktor lelang dan pengadaan barang dan jasa menjadi faktor yang paling dominan dalam kaitannya dengan pola penyerapan slow-back loaded yang terjadi selama tahun 2017.

Tabel 9. Komposisi Belanja Yang Dikontrakkan

\begin{tabular}{|l|r|r|r|}
\hline \multicolumn{1}{|c|}{ Jenis Belanja } & Realisasi TA 2017 & $\begin{array}{c}\text { Realisasi Belanja } \\
\text { Yang Dikontrakkan }\end{array}$ & $\begin{array}{c}\% \text { Nilai } \\
\text { Kontrak } \\
\text { Thd } \\
\text { Realisasi }\end{array}$ \\
\hline Belanja Barang & 3.428 .434 .009 .144 & 788.576 .834 .700 & $23,00 \%$ \\
\hline Belanja Modal & 2.398 .177 .729 .128 & 1.967 .490 .138 .881 & $82,04 \%$ \\
\hline
\end{tabular}

\begin{tabular}{|c|r|r|r|}
\hline $\begin{array}{l}\text { Belanja Bantuan } \\
\text { Sosial }\end{array}$ & 39.314 .002 .800 & 2.873 .127 .800 & $7,31 \%$ \\
\hline Total & 5.865 .925 .741 .072 & 2.758 .940 .101 .381 & $47,03 \%$ \\
\hline
\end{tabular}

Sumber : Kanwil DJPb Prov Sumbar, diolah

\section{Faktor Perubahan Kebijakan Internal}

Faktor perubahan kebijakan internal satuan kerja dan $\mathrm{K} / \mathrm{L}$ yang mejelaskan seluruh item sebesar 6,548\% merupakan faktor dominan kedua yang menyebabkan permasalahan penyerapan anggaran belanja APBN di Sumatera Barat. Adanya revisi ataupun addendum kontrak, seringkali dianggap memperlambat realisasi anggaran. Hal ini dikarenakan adanya penyesuaian-penyesuaian yang harus dilakukan sehingga memakan waktu yang cukup lama. Selain itu, adanya tambahan pagu dalam DIPA khususnya yang dianggarkan melalui APBN-P tahun 2017, ataupun adanya dana luncuran Pinjaman dan Hibah Luar Negeri (PHLN) dan Pinjaman dan Hibah Dalam Negeri (PHDN) membuat satker K/L di Provinsi Sumatera Barat kesulitan dalam merealisasikan tambahan anggaran tersebut di semester 2 TA 2017. Lambatnya pengajuan atau pengisian kembali Uang Persedian (UP) melalui pengajuan Ganti Uang Persediaan (GUP) untuk kegiatan-kegiatan yang telah selesai dilaksanakan juga diakui oleh satuan kerja sebagai dampak dari perubahan kebijakan internal satker dan K/L. Data yang didapat dari Kanwil DJPb Provinsi Sumatera Barat menyatakan bahwa dari total 15.435 SPM GUP yang diajukan selama TA 2017, sebanyak 2.076 SPM GUP $(13,45 \%)$ diajukan terlambat atau melebihi waktu yang telah di atur dalam PMK Nomor 190 Tahun 2012 (diajukan melewati 1 bulan). Hal ini tentu berpengaruh pada keterlambatan penyerapan anggaran di level satuan kerja.

\section{Faktor Administrasi Perencanaan Anggaran}

Faktor administrasi perencanaan anggaran yang menjelaskan seluruh item sebesar 4,815\% merupakan faktor berikutnya yang mempengaruhi pola slow back-loaded yang terjadi di satker K/L Provinsi Sumatera Barat. Masih adanya DIPA yang terlambat diterima oleh satker menyebabkan beberapa kegiatan tidak dapat dieksekusi sesuai dengan perencanaan yang telah di buat sebelumnya. Hal ini secara langsung menyebabkan keterlambatan pada proses pencairan anggaran. Selain itu masih adanya tanda blokir atau bintang dalam dokumen pelaksanaan anggaran (DIPA) yang diakibatkan karena kurangnya data pendukung kegiatan, juga dianggap sebagai faktor 
yang akhirnya berpengaruh pada keterlambatan penyerapan anggaran. Untuk diketahui proses menghilangkan blokir atau tanda bintang pada DIPA membutuhkan waktu yang cukup lama karena proses revisi DIPA harus diajukan terlebih dahulu ke eselon I atau kantor pusat satker yang bersangkutan sebelum diajukan ke Direktorat Jenderal Anggaran untuk proses penghapusan tanda bintang di DIPA. Adapun selama tahun 2017 dari 751 satker yang ada di Sumatera Barat, terdapat 65 satker $(8,66 \%)$ yang memiliki tanda bintang/blokir di DIPA.

\section{Faktor Pejabat Perbendaharaan}

Faktor Pejabat Perbendaharaan yang menjelaskan seluruh item sebesar $4,602 \%$ merupakan faktor keempat yang dianggap mempengaruhi pola penyerapan yang terjadi di Sumatera Barat. Faktor ini lebih diakibatkan karena keengganan ataupun ketakutan dari pegawai satker untuk menjadi pejabat perbendaharaan dalam hal ini KPA, PPK, PPSPM ataupun Bendahara Pengeluaran yang disebabkan karena tidak seimbangnya resiko pekerjaan dengan imbalan yang diterima. Selain itu masih ditemukan banyaknya pejabat perbendaharaan yang takut untuk melaksanakan atau mengeksekusi pengadaan barang dan jasa akibat banyaknya pemberitaan penangkapan pegawai/pejabat dengan tuduhan korupsi dan pemberitaan negatif lainnya. Hal ini ditemukan seringkali menghambat pencairan dana yang semestinya dapat dilaksanakan lebih cepat.

\section{Faktor Perubahan Kebijakan Pemerintah}

Faktor yang kelima adalah faktor perubahan kebijakan pemerintah yang menjelaskan seluruh item sebesar 3,875\%. Faktor ini terkait dengan masih sering terjadinya perubahan struktur organisasi ataupun nomenklatur satuan kerja sehingga menyebabkan dokumen pelaksanaan anggaran harus direvisi ke DJA. Hal ini meskipun tidak secara dominan mempengaruhi penyerapan anggaran, akan tetapi tetap mempunyai pengaruh dalam memperlambat penyerapan yang seharusnya dapat dilakukan lebih awal. Selain itu adanya kebijakan penghematan anggaran dari Pemerintah, juga seringkali menyebabkan satker harus membuat perencanaan ulang terhadap kegiatan-kegiatan yang sudah direncanakan sebelumnya, dan akhirnya menyebabkan keterlambatan pada proses pencairan dana.

\section{Faktor Verifikasi Dokumen Untuk Pelaksanaan Anggaran}

Faktor terakhir yang menjadi penyebab permasalahan penyerapan anggaran belanja APBN TA 2017 di Provinsi Sumatera Barat adalah faktor verifikasi dokumen untuk pelaksanaan anggaran. Faktor ini menjelaskan seluruh item atau variabel sebesar 3,129\%. Hal yang utama terkait dengan faktor ini adalah masih tingginya volume revisi anggaran baik yang diajukan ke Kanwil DJPb Provinsi Sumatera Barat maupun yang diajukan ke DJA. Selain itu revisi Petunjuk Operasional Kegiatan (POK) yang merupakan kewenangan dari KPA Satker, juga masih sering ditemukan di tahun 2017. Proses revisi itu sendiri meskipun diberikan agar pelaksanaan anggaran lebih fleksibel terhadap adanya perubahan-perubahan yang tidak direncanakan sebelumnya, akan tetapi di sisi yang lain menandakan bahwa proses perencanaan yang dibuat oleh satker belum sepenuhnya baik.

\section{KESIMPULAN DAN SARAN}

\subsection{Kesimpulan}

Berdasarkan identifikasi dan analisis permasalahan dengan menggunakan Exploratory Factor Analysis (EFA) maka dapat disimpulkan bahwa faktor-faktor penyebab keterlambatan penyerapan anggaran belanja APBN 2017 pada satuan kerja lingkup Provinsi Sumatera Barat secara umum hampir sama dengan faktor-faktor penyebab permasalahan penyerapan anggaran yang ditemukan oleh peneliti-peneliti sebelumnya. Lima faktor yang paling dominan menyebabkan pola slow back-loaded di Sumatera Barat berdasarkan total variance nya adalah :

a. Faktor proses lelang dan pengadaan barang dan jasa dengan total variance $41,065 \%$

b. Faktor perubahan kebijakan internal satuan kerja dan kementerian/lembaga dengan total variance $6,548 \%$

c. Faktor administrasi perencanaan anggaran dengan total variance $4,815 \%$

d. Faktor pejabat perbendaharaan dengan total variance $4,602 \%$

e. Faktor perubahan kebijakan pemerintah dengan total variance $3,875 \%$, dan

f. Faktor verifikasi dokumen untuk pelaksanaan anggaran dengan total variance $3,129 \%$

Kelima faktor tersebut secara total memiliki variasi yang menjelaskan permasalahan penyerapan anggaran di Sumatera Barat sebanyak 64,034\%. Adapun sisa $35,966 \%$ nya dijelaskan oleh faktorfaktor lain selain kelima faktor amatan tersebut.

\subsection{Saran}

Adapun dalam mengatasi permasalahan terkait dengan keterlambatan penyerapan anggaran belanja APBN yang menyebabkan terjadinya pola slow-back loaded di Provinsi Sumatera Barat, saran penulis terhadap permasalahan yang terjadi adalah sebagai berikut: 
1. Terkait dengan Proses Pengadaan Barang dan Jasa, pimpinan satker dapat

- Membuat jadwal pelaksanaan kegiatan/ jadwal pengadaan barang/jasa lebih cepat bahkan disarankan sebelum tahun anggaran dimulai. Hal ini dimaksudkan agar proses lelang dapat segera dilakukan sebelum memasuki tahun anggaran berkenaan atau di awal-awal tahun anggaran. Selain itu kegiatan monitoring dan evaluasi terhadap pelaksanaan kegiatan harus dilakukan secara berkala atas kegiatan yang telah dan akan dilaksanakan.

- Menugaskan kepada pegawai di lingkup satker agar mengikuti diklat terkait pengadaan barang dan jasa dan menjalin koordinasi dengan pihak ULP di Kementerian lain apabila belum terbentuk ULP di Kementerian tersebut, sehingga proses pengadaan barang dan jasa tidak terhambat.

- Memasukkan kinerja panitia/pejabat pengadaan barang dan jasa sebagai salah satu Key Performance Indicators (KPI) satuan kerja.

2. Terkait dengan faktor perubahan kebijakan internal, pimpinan satker disarankan untuk

- Berkoordinasi lebih awal dengan unit eselon I Kementerian/Lembaga nya terkait dengan adanya tambahan pagu DIPA melalui APBNP. Hal ini dimaksudkan agar satker lebih siap mengantisipasi pelaksanaan kegiatan yang akan timbul dari adanya tambahan pagu yang diberikan

- Segera melalukan revolving atas dana Uang Persediaan yang telah digunakan apabila telah mencapai 50\% dari dana UP yang diterima. Proses pengajuan SPM GUP tidak harus menunggu Uang Persedian seluruhnya terpakai. Selain itu disarankan agar satker melakukan perhitungan secara terinci mengenai jumlah riil UP yang dibutuhkan dalam satu bulan. Hal tersebut untuk menghindari pengajuan UP yang terlalu besar sehingga berakibat pada lamanya pengajuan GUP yang pada akhirnya akan berakibat pada keterlambatan penyerapan anggaran.

3. Terkait dengan Faktor Administrasi Perencanaan Anggaran, satker diharapkan untuk :

- Berkoordinasi dengan unit eselon I nya, agar proses pencetakan dan pendistribusian DIPA oleh Direktorat Jenderal Anggaran (DJA) dapat dipercepat sehingga proses pelaksanaan pekerjaan dapat segera dimulai. Pada level kebijakan di Kementerian Keuangan, disarankan agar pencetakan dan pendistribusian seluruh DIPA satker dapat dilakukan sebelum tahun anggaran dimulai. Hal ini akan mendorong pelaksanaan kegiatan dan penyerapan anggaran yang lebih cepat.

- Meminimalisir tanda blokir pada DIPA satker. Hal ini dapat dilakukan satker dengan cara membuat perencanaan yang matang dan detil terkait dengan prioritas kegiatan yang akan dilaksanakan. Selain itu, satker diharapkan mempunyai dokumen perencanaan (TOR/RAB) dan seluruh dokumen yang dipersyaratan dengan lengkap sebelum proses pembahasan RKAKL dimulai. Hal ini dapat membantu satker dalam menghindari tanda blokir yang sering muncul di DIPA.

4. Terkait dengan faktor pejabat perbendaharaan, direkomendasikan agar reward atau penghargaan yang diberikan kepada para pejabat perbendaharaan disesuaikan dengan faktor resiko yang diembannya. Reward atau penghargaan dapat diberikan dalam bentuk kenaikan insentif atau honor yang diatur dalam Standar Biaya Masukan (SBM) yang dibuat oleh DJA Kementerian Keuangan. Selain itu, dari internal satker, reward dapat diberikan dalam bentuk pengakuan atas kinerja yang baik dari para pimpinan kementerian/lembaga kepada para pejabat perbendaharaan di level satuan kerja.

5. Terkait dengan faktor perubahan kebijakan pemerintah dengan adanya perubahan nomenklatur atau struktur organisasi satker, direkomendasikan agar proses revisi anggaran dapat lebih disederhanakan. Apabila dimungkinkan, proses kewenangan revisi tersebut dapat dilimpahkan ke Kanwil DJPb agar proses revisi DIPA satker dapat dilakukan dengan lebih cepat. Hal ini juga sesuai dengan semangat simplifikasi dan efektivitas pelaksanaan kegiatan yang sedang digalakkan khususnya di lingkungan Kementerian Keuangan.

6. Terkait dengan masih tingginya angka revisi anggaran satker di Sumatera Barat dan untuk meningkatkan kehati-hatian dalam perencanaan serta komitmen terhadap kegiatan yang telah direncanakan, disarankan agar Kantor Pusat Ditjen Perbendaharaan agar berkoordinasi dengan Ditjen Anggaran untuk melakukan kajian terhadap pembatasan frekuensi revisi anggaran. Diusulkan agar revisi pergeseran anggaran maksimal dilaksanakan sebanyak 2 kali dalam satu tahun anggaran. 


\section{IMPLIKASI DAN KETERBATASAN}

\subsection{Implikasi}

Penelitian ini diharapkan dapat bermanfaat bagi seluruh stakeholders terkait yaitu satuan kerja, KPPN, Kanwil DJPb, Kantor Pusat DJPb dan DJA. Diharapkan hasil penelitian ini dapat dijadikan sebagai bahan masukan dalam pembuatan kebijakan yang lebih baik di masa yang akan datang.

Selain itu, penelitian ini juga diharapkan dapat menjadi salah satu pilihan literatur dan bahan diskusi akademis oleh semua pihak yang berkepentingan, khususnya terkait dengan permasalahan penyerapan APBN.

\subsection{Keterbatasan}

Penelitian ini memiliki keterbatasan teknis berupa terbatasnya responden data primer yang digunakan. Dari 751 satker yang ada di Provinsi Sumatera Barat, jumlah responden yang digunakan dalam penelitian ini hanya sebanyak 200 responden atau satker. Akan tetapi jumlah responden telah memenuhi batas minimal untuk dilakukan analisis faktor yaitu 175 responden.

Selain itu penelitian juga terbatas hanya pada satuan kerja di wilayah kerja Kanwil DJPb Provinsi Sumatera Barat. Hal ini menyebabkan justifikasi atau hasil kesimpulan hanya mampu menerangkan permasalahan pada satker-satker lingkup Provinsi Sumatera Barat.

Untuk penelitian berikutnya disarankan untuk mengambil jumlah sampel atau responden yang lebih besar. Selain itu penelitian juga dapat meggunakan objek penelitian yang tidak hanya difokuskan pada satu wilayah kerja atau provinsi untuk mendapatkan kesimpulan atau justifikasi yang lebih komprehensif. Penelitian juga dapat mengekplorasi metode atau teknik analisis faktor yang lain, misalnya dengan menggunkan teknik analisis faktor konfirmatori atau Confirmatory Factor Analysis (CFA).

\section{PENGHARGAAN}

Penulis ingin mengucapkan terima kasih kepada seluruh pihak yang berkontribusi besar dalam membantu penulis menyelesaikan penelitian ini khususnya kepada seluruh jajaran pegawai di lingkup Kanwil DJPb Provinsi Sumatera Barat. Penghargaan secara pribadi penulis sampaikan kepada Bapak Kepala Kanwil DJPb Provinsi Sumatera Barat, Ade Rohman dan Kepala Bidang Pembinaan Pelaksanaan Anggaran I Kanwil $\mathrm{DJPb}$ Provinsi Sumatera Barat, Bapak Sudirman, yang telah memberikan ijin dan dukungan kepada penulis sehingga penelitian ini dapat diselesaikan dengan baik. Selain itu, penghargaan serupa penulis haturkan kepada seluruh Kepala KPPN beserta staff di lingkup Kanwil DJPb Provinsi Sumatera Barat (KPPN Padang, KPPN Bukittinggi, KPPN Solok, KPPN Painan, KPPN Sijunjung dan KPPN Lubuk Sikaping) yang telah membantu penulis dalam menyebarkan kuesioner penelitian kepada para satuan kerja di lingkup wilayah kerja KPPN masing-masing.

\section{DAFTAR PUSTAKA}

Baridwan, Z. (2012). Analisis Faktor-Faktor Yang Mempengaruhi Penumpukan Penyerapan Anggaran Belanja Pada Akhir Tahun Anggaran. [Yogyakarta]: Universitas Gadjah Mada.

Freeman, R. (1972). Municipal budgeting, accounting, reporting and auditing $1972-$ 1999. Alabama Municipal Journal, 29(10).

Guilford, J. P. (1965). Fundamental Statistics in Psychology and Education: New York: McGraw-Hill.

Hair, J. F., Black, W. C., Babin, B. J., Anderson, R. E., \& Tatham, R. L. (1998). Multivariate data analysis (Vol. 5): Prentice hall Upper Saddle River, NJ.

Halim, A. (2013). Manajemen keuangan sektor publik, problematika penerimaan dan pengeluaran pemerintah (Anggaran Pendapatan dan Belanja Negara/Daerah). Penerbit Salemba Empat. Jakarta.

Herriyanto, H. (2012). Faktor-Faktor yang Mempengaruhi Keterlambatan Penyerapan Anggaran Belanja pada Satuan Kerja Kementerian/Lembaga di Wilayah Jakarta. Thesis, Jakarta: Fakultas Ekonomi, Universitas Indonesia.

Identifying the Constraints to Budget Execution in the Infrastructure Sector - DIPA Tracking Study. (2012). World Bank.

Johnson, R. A., \& Wichern, D. (2002). Multivariate analysis: Wiley Online Library.

Kuswoyo, I. D. (2012). Analisis atas Faktor-Faktor yang Menyebabkan Terkonsentrasinya Penyerapan Anggaran Belanja di Akhir Tahun Anggaran (Studi pada Satuan Kerja di Wilayah KPPN Kediri). [Yogyakarta]: Universitas Gadjah Mada.

Nugroho, M. A., \& Ananda, C. F. (2012). Analisis Faktor-Faktor Yang Menyebabkan Penumpukan Pencairan Dana APBN Di Akhir Tahun (Studi Kasus Di KPPN Malang). Jurnal Ilmiah Mahasiswa FEB, 1(2). 
Rummel, R. J. (1988). Applied factor analysis: Northwestern University Press.

Santoso, S. (2017). Statistik Multivariat dengan SPSS: Elex Media Komputindo.

Setyawan, A. (2017). Analisis Keterlambatan Penyerapan Anggaran Belanja Satuan Kerja Kementerian/Lembaga di Wilayah Pembayaran KPPN Bojonegoro Tahun Anggaran 2015. Thesis, Surabaya: Fakultas Ekonomi, Universitas Airlangga.

Singarimbun, M., \& Effendi, S. (1989). Metodologi penelitian survey. Jakarta: Pustaka LP3 ES.

Siswanto, A. D., \& Rahayu, S. L. (2010). FaktorFaktor Penyebab Rendahnya Penyerapan Belanja Kementerian/Lembaga TA 2010. Policy Paper Pusat Kebijakan APBN.

Suparmoko, M. (2000). Keuangan negara: Dalam teori dan praktek: BPFE.

Supranto, J. (2004). Analisis Multivariat Arti dan Interpretasi. Rineka Cipta, Jakarta.

Widarjono, A. (2015). Analisis Multivariat Terapan Dengan Program SPSS, AMOS, dan SMARTPLS. UPP STIM YKPN: Yogyakarta.

Yamin, S., \& Kurniawan, H. (2009). SPSS Complete: Teknik Analisis Statistik Terlengkap dengan Software SPSS. Jakarta: Salemba Infotek. 